\title{
ResearchOnline@JCU
}

This is the Accepted Version of a paper published in the journal:

Archaeological Prospection

Kenady, Selene L., Lowe, Kelsey M., Ridd, Peter V., and Ulm, Sean (2018)

Creating volume estimates for buried shell deposits: a comparative experimental case study using ground-penetrating radar (GPR) and electrical resistivity under varying soil conditions. Archaeological Prospection, 21 (2). pp. 121-136.

http://dx.doi.org/ 10.1002/arp.1594

(C) 2015. This manuscript version is made available under the CC-BY-NC-ND 4.0 license

http://creativecommons.org/licenses/by-nc-nd/4.0/

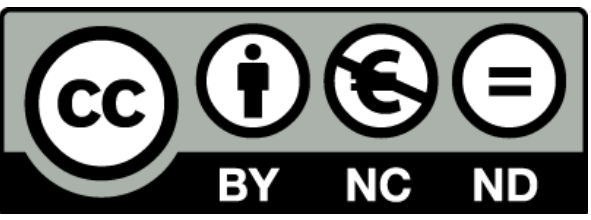


Creating Volume Estimates for Buried Shell Deposits: A Comparative Experimental Case Study using Ground-Penetrating Radar (GPR) and Electrical Resistivity under Varying Soil Conditions

Selene L. Kenady ${ }^{1 *}$, Kelsey M. Lowe ${ }^{2,3}$, Peter V. Ridd ${ }^{4}$ and Sean Ulm ${ }^{1,5}$

1 College of Arts, Society and Education, James Cook University, PO Box 6811, Cairns, QLD 4870, Australia

2 Institute of Resilient Regions, School of Arts and Communication, The University of Southern Queensland, Toowoomba, QLD 4350, Australia

3 School of Social Science, The University of Queensland, Brisbane, QLD 4872, Australia

4 College of Science and Engineering, James Cook University, Townsville, QLD 4811, Australia

5 ARC Centre of Excellence for Australian Biodiversity and Heritage, James Cook University, PO Box 6811, Cairns, QLD 4870 Australia

* Corresponding author

\section{Funding sources}

This research was supported by an Australian Postgraduate Award Scholarship. 


\begin{abstract}
Sampling issues represent a persistent problem in shell matrix research, particularly for large shell deposits. When small samples are taken from large buried deposits it is almost impossible, under current research practices, to understand how representative that sample is of the overall deposit. This case study tests a novel method for creating a better understanding of the buried deposits from which excavated samples are taken, thereby allowing for improved sampling strategies and a better understanding of how representative those samples are of the overall site. The case study employs two geophysical survey methods, ground-penetrating radar (GPR) and electrical resistivity, to investigate buried shell deposits under experimental conditions. The survey results were used to create volume estimations and three-dimensional (3D) models of buried shell deposits. This method is novel to shell matrix research and the current case study was designed to test the viability of the method under differing conditions. As well as testing the two geophysical methods, surveys were conducted under different moisture levels, soil types and survey transect spacings. Results showed that the $3 \mathrm{D}$ models and volumes estimates of the deposit were successful in creating a representative understanding of the nature of the buried deposit, but with varying degrees of accuracy. GPR results created more accurate volume estimates and 3D models than the electrical resistivity results. Both geophysical methods produced more accurate results under drier conditions, though the electrical resistivity produced more visually distinct results with higher moisture levels. Analysis of the volume results revealed an error margin (to a confidence level of $95 \%$ ) of $9.5 \% \pm 15.5 \%$ for the GPR, and $44.5 \% \pm 31.5 \%$ to $56 \pm 70.5 \%$ for the electrical resistivity, depending on the interpretation method used to create the models.
\end{abstract}

\title{
Keywords
}

Geophysics; shell matrix; shell midden; ground-penetrating radar; electrical resistivity 


\section{Introduction}

Large coastal shell matrix sites pose complex sampling considerations for archaeological excavation. These sites are notoriously challenging to sample as determining what constitutes a representative sample requires an understanding of the size of the buried deposits, and the structural variability within them. Excavation currently represents the main method for both sampling a shell matrix site and for establishing an understanding of the nature of the buried deposits. With current archaeological research regimes moving towards smaller and more limited test pits (Langley et al. 2011; Ulm 2002), which represent only a tiny sample of a large shell matrix site, it is difficult to evaluate how representative these samples are of the whole matrix. Extensive excavation regimes are, however, undesirable both in terms of expense and destruction of the archaeological record.

Sampling issues in archaeological shell matrix research have largely been ignored, with researchers in the field simply concluding that the only appropriate sampling regimes are those tailored to meet specific research aims (e.g. Ambrose 1967; Bowdler 2014; Claassen 1998; Waselkov 1987). The limited research that has been conducted to address sampling issues includes O'Neil (1993), Poteate and Fitzpatrick (2013), and Treganza and Cook (1948) who all excavated large proportions of shell matrix sites in order to establish the sampling size and/or sampling strategy required to produce an accurate understanding of the shell population of the entire matrix. Alternatively, Bailey (1975) and Greenwood (1961) focused on how much of the excavated shell material needed to be analysed in detail to accurately characterise the overall sample. However these studies produced varying results from which little could be universally applied.

This current research proposes that geophysical surveys could represent a non-invasive and precise way to create a greater understanding of buried shell matrix sites. Our experimental case study aims to test whether geophysical methods can be used to create three-dimensional (3D) models and volume estimates of buried deposits thereby allowing for a greater understanding of the overall nature of the site and the population from which excavated samples were taken. Little research has been conducted in the application of geophysical survey methods to shell matrix deposits. An extensive literature review revealed 23 papers representing 18 case studies of which three were geological rather than archaeological (Table 1).

These studies focused on locating shell deposits or features within deposits. None of the studies utilised geophysical surveys to create 3D models of buried deposits and only one (Larsen et al. 2017) attempted to quantify the deposit. Larsen et al. (2017) employed terrestrial laser scanning (TLS) to create volume estimates of shell mounds, however this method can only map the mounded matrix above the surrounding ground plane and cannot differentiate the shell matrix deposit from surrounding deposits. In order to generate a method for creating volume estimates and 3D models of buried shell matrix deposits from geophysical survey results, research from other fields was reviewed. Geological studies, particularly in glacial research, had previously employed geophysical surveys to create volume estimates. A sampling of this literature found that GPR was the favoured geophysical survey method, however electrical resistivity was represented also (Table 2). Both techniques produce results that facilitate the creation of three-dimensional models and volume estimates of buried shell deposits. 
This study employs both GPR and electrical resistivity to transform the survey results into volume estimates and 3D models of the deposits using a methodology that is detailed in Kenady et al. (in press) and Kenady (2017). The methods were tested under experimental conditions so that results from the modelling could be compared to the actual in-ground deposits to test each geophysical method's accuracy in generating volume calculations and 3D models of the buried shell deposits. The experimental design allowed for control over the size and structure of the shell deposits being investigated, and the ability to monitor the conditions present in the experimental set up to determine the effects of those conditions on the GPR and electrical resistivity surveys. Three significant variables and their effect on the geophysical survey results were investigated: 1) the type of sediment surrounding the shell matrix, 2) the moisture content of that sediment; and 3) the spacing of transect lines during survey.

Table 1. Summary of geophysical studies investigating shell matrix sites, by geophysical technique.

\begin{tabular}{|c|c|c|c|c|c|c|}
\hline Publication & Magnetometry & $\begin{array}{l}\text { Magnetic } \\
\text { Susc. }\end{array}$ & EM & GPR & $\begin{array}{l}\text { Electrical } \\
\text { Res. }\end{array}$ & Other \\
\hline Arias et al. (2017) & $\mathbf{x}$ & & & & & \\
\hline Arnold et al. (1997) & $\mathbf{x}$ & & & $\mathbf{x}$ & & \\
\hline Bērziṇš et al. (2014) & $\mathbf{x}$ & & & $\mathbf{x}$ & & \\
\hline Chadwick and Madsen (2000) & & & & $\mathbf{x}$ & & \\
\hline Connah et al. (1976) & $\mathbf{x}$ & $\mathbf{x}$ & & & & \\
\hline Dalan et al. (1992) & $\mathbf{x}$ & & & & $\mathbf{x}$ & $\begin{array}{l}x \text { (seismic } \\
\text { refraction) }\end{array}$ \\
\hline Dougherty and Dickson (2012) & & & & $\mathbf{x}$ & & \\
\hline Larsen et al. (2017) & & & & & & $x$ (TLS) \\
\hline Lowe (2010) & & & & & $\mathbf{x}$ & \\
\hline Moffat et al. (2008) & $\mathbf{x}$ & & $\mathbf{x}$ & & & \\
\hline Neal et al. (2002) & & & & $\mathbf{x}$ & & \\
\hline Pluckhahn et al. (2009) & & & & $\mathbf{x}$ & $\mathbf{x}$ & \\
\hline Pluckhahn et al. (2010) & & & & $\mathbf{x}$ & $\mathbf{x}$ & \\
\hline Pluckhahn et al. (2016) & & & & $\mathbf{x}$ & & \\
\hline Rodrigues et al. (2009) & & & $\mathbf{x}$ & $\mathbf{x}$ & & \\
\hline Rodrigues et al. (2015) & & & & $\mathbf{x}$ & & \\
\hline Rosendahl et al. (2014) & & $\mathbf{x}$ & & & & \\
\hline Santos et al. (2009) & & & $\mathbf{x}$ & & & \\
\hline Thompson (2007) & & & & & $\mathbf{x}$ & \\
\hline Thompson and Andrus (2011) & & & & & $\mathbf{x}$ & \\
\hline $\begin{array}{l}\text { Thompson and Pluckhahn } \\
\text { (2010) }\end{array}$ & & & & $\mathbf{x}$ & $\mathbf{x}$ & \\
\hline Thompson et al. (2004) & $\mathbf{x}$ & & $\mathbf{x}$ & $\mathbf{x}$ & $\mathbf{x}$ & \\
\hline Weill et al. (2012) & & & & $\mathbf{x}$ & & \\
\hline
\end{tabular}


Table 2. Breakdown by geophysical technique of papers utilising geophysical surveys to create volume estimates.

\begin{tabular}{|c|c|c|c|c|}
\hline Publication & Geological Medium & GPR & Electrical Res. & TLS \\
\hline Ai et al. (2014) & Glacier ice & $\mathbf{x}$ & & \\
\hline Baojuan et al. (2015) & Glacier ice & $\mathbf{x}$ & & \\
\hline Binder et al. (2009) & Glacier ice & $\mathbf{x}$ & & \\
\hline Colucci et al. (2015) & Glacier ice & $\mathbf{x}$ & & \\
\hline Dickson et al. (2009) & Beach sand & $\mathbf{x}$ & & \\
\hline Kristiansen (2013) & Perennial snow patch & $\mathbf{x}$ & & \\
\hline Larsen et al. (2017) & Shell matrix & & & $\mathbf{x}$ \\
\hline Navarro et al. (2014) & Glacier ice & $\mathbf{x}$ & & \\
\hline Nowroozi et al. (1997) & Gravel deposits & & $\mathbf{x}$ & \\
\hline Prinz et al. (2011) & Glacier ice & $\mathbf{x}$ & & \\
\hline Rucker et al. (2011) & Dredgable river sediments & & $\mathbf{x}$ & \\
\hline Sambuelli and Bava (2012) & Lake water & $\mathbf{x}$ & & \\
\hline Tetegan et al. (2012) & Rock fragments & & $\mathbf{x}$ & \\
\hline Van Heteren et al. (1996) & Beach sand & $\mathbf{x}$ & & \\
\hline Wang et al. (2014) & Glacier ice & $\mathbf{x}$ & & \\
\hline Yde et al. (2014) & Glacier ice & $\mathbf{x}$ & & \\
\hline
\end{tabular}

\section{Material and Methods}

The geophysical instruments employed were a MAL $\AA$ GeoScience GPR, utilising a 500MHz shielded antenna with the Ramac XV monitor and the X3M control box, and an Advanced Geosciences, Inc. Resistivity meter consisting of a MiniSting ${ }^{\mathrm{TM}}$ control unit and Swift ${ }^{\mathrm{TM}}$ electrode cable with 28 electrodes. Standard settings were applied over several rounds of surveying.

The GPR system was standardly set so the number of samples was 1016 and trace stacking was set to four. For the electrical resistivity array an electrode separation of $25 \mathrm{~cm}$ was employed throughout, and the system was standardly set to maximum cycles of 2 , with a current setting of $200 \mathrm{~mA}$ which the system will automatically downgrade if required (Advanced Geosciences, Inc. 2003:39-40). The system was set to 200 volts for the sediment-rich experimental trench, and to 400 volts for the sand-filled trench to combat contact resistance problems.

\subsection{Survey Site}

The experimental site consisted of two separate $2 \mathrm{~m} \times 4 \mathrm{~m}$ trenches (Trench 1 and 2) excavated to a depth of $1 \mathrm{~m}$. Trench 2 was placed to the west of, and aligned with, Trench 1 with a baulk of $2 \mathrm{~m}$ between the two (Figure 1). Once excavated, Trench 1 was re-filled with coarse washed sand, analogous to the environment in which archaeological shell deposits are typically found in northern tropical Australia (e.g. Faulkner 2013; Twaddle et al. 2017). Trench 2 was filled with a garden soil mix designed to represent the more organic-rich sediments that shell matrices can be found in around the world. Oyster shell was placed into both trenches to represent buried shell matrix deposits. As fresh oyster shell was employed these experimental shell matrices will not represent a good proxy for sites with degraded shell material. Differing states of perseveration will change the electrical and physical properties of shell material and its surrounding sediment, which will in turn have an effect on the geophysical results, and the accuracy of the models and volume estimates produced. This study can, therefore, only represent results for sites with well-preserved shell material. 
All oyster shell for the experiment was counted establishing both the minimum number of individuals (MNI) and the number of identified specimens (NISP), before being weighed and then measured for volume via water displacement (Table 3). The oyster shells were an average size of $77 \mathrm{~mm}$ in length by $47 \mathrm{~mm}$ width and consisted predominantly of the lids (right sides). The actual volume of the shell $\left(223,340 \mathrm{~cm}^{3}\right.$ or $\left.0.22 \mathrm{~m}^{3}\right)$ does not account for the total space occupied by the shell as they do not lie flat together.

The shell was placed in two discreet layers in each trench (Figures 1-2). These two layers measured 1m wide by $1.5 \mathrm{~m}$ long to an approximate depth of $10 \mathrm{~cm}$, making the volume of the space they occupied $\mathrm{c} .0 .15 \mathrm{~m}^{3}$ per layer (a total of $0.6 \mathrm{~m}^{3}$ for the four layers). The first layer was placed directly on the basal clay of the trenches and was situated in the middle of the trenches $1 \mathrm{~m}$ in from the eastern end. The second layer was situated c. $42 \mathrm{~cm}$ above the first layer, also in the middle of the trenches but $1 \mathrm{~m}$ in from the western end, so it partially overlapped the lower deposit. Shell deposit and trench dimensions/depth were recorded with reference to a local datum via an optical dumpy level.

The experimental site was surveyed using strict grid control. A survey grid was established over the two trenches with survey lines established every $50 \mathrm{~cm}$. Each trench was surveyed separately with GPR and electrical resistivity lines, with both lines beginning and ending beyond the respective trench boundaries. The survey grid was established to align with a datum marking the corners of each trench (these were outside the geophysical survey lines). This was done so the grid could be easily relocated in the same position for replicate surveys. The GPR lines were run first for each round of surveying, so their results were not affected by the additional water that was applied to the electrical resistivity electrodes to aid their contact with the ground. Usually salt water is used for this process as it is more conductive but for this experiment freshwater was used so that any future GPR surveys would not be adversely affected by the addition of salt and the associated enhanced conductivity which would accelerate the attenuation of the radar wave.

The experiment included both 'wet' and 'dry' geophysical surveys as water content has a significant effect on both GPR and electrical resistivity. If the shell deposits retained water at a rate different to the surrounding sediment this could affect the response they produce in the geophysical survey data and in turn affect the results of the modelling and volume estimations. The 'wet' surveys were conducted immediately after heavy rainfall, while the 'dry' surveys took place after a 10 day interval of no rain. The water content analysis found that during these 10 days, the organic matrix of Trench 2 drained more quickly and dried out more than the sand matrix of Trench 1 (Tables 4-6).

To establish the water volume present for each survey, a small pit was dug into the middle of the western end of each trench from which soil cores were taken in steel bulk density rings $(75 \mathrm{~mm}$ diameter by $50 \mathrm{~mm}$ height). Samples were taken at the surface (approximately $2 \mathrm{~cm}$ depth as the surface was cleared first), then at $40 \mathrm{~cm}$ and $80 \mathrm{~cm}$. Two samples were taken at each depth so that they could be averaged. The soil cores were then weighed in the laboratory using a Shimadzu ATY224 electronic balance to the nearest $0.01 \mathrm{~g}$ before being oven-dried for 48 hours at $105^{\circ} \mathrm{C}$. Once thoroughly dried the core was weighed again. These weights were used to create gravimetric water content $(\theta \mathrm{g})$ values (Equation 1$)$ which are expressed as the percentage of water present per $100 \mathrm{~g}$ of soil. 
$\theta \mathrm{g}=$ (weight of wet soil - weight of dry soil) / weight of dry soil (Equation 1)

An average of these values for each depth $(2 \mathrm{~cm}, 40 \mathrm{~cm}$ and $80 \mathrm{~cm})$ are presented in Tables 5 and 6 . For comparison, laboratory analysis was also used to create saturated and field capacity values for each sediment, as with the field samples, these were conducted twice, and the results averaged (Table 4). Field capacity is the volume of water remaining in the soil 2-3 days after rainfall and drainage (Soil Science Society of America 1997:40). Saturated and field values were determined by first saturating the samples from the bottom up, to remove any air from the sediment. The saturated samples were then weighed, and oven dried. The field capacity samples were saturated then placed on a 1 bar ceramic suction plate (drained over $1 \mathrm{~m}$ to create 10 kilopascals of pressure) and left to drain for approximately 48 hours before being weighed, and oven dried; this is the standard laboratory method for creating field capacity values (Cresswell 2002:64-67).

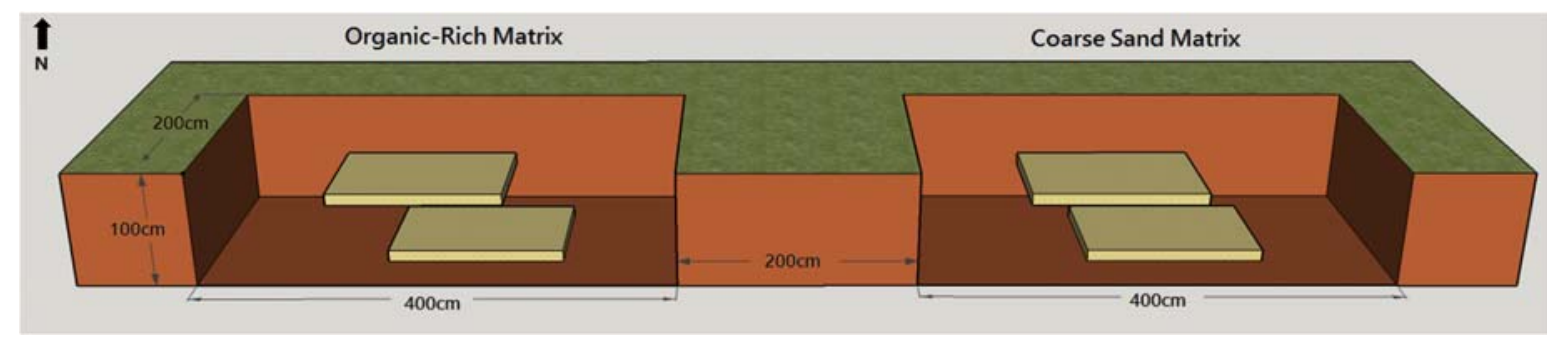

Figure 1. Layout of Trench 1 and 2 in relation to one another, including the location of their respective shell deposits.

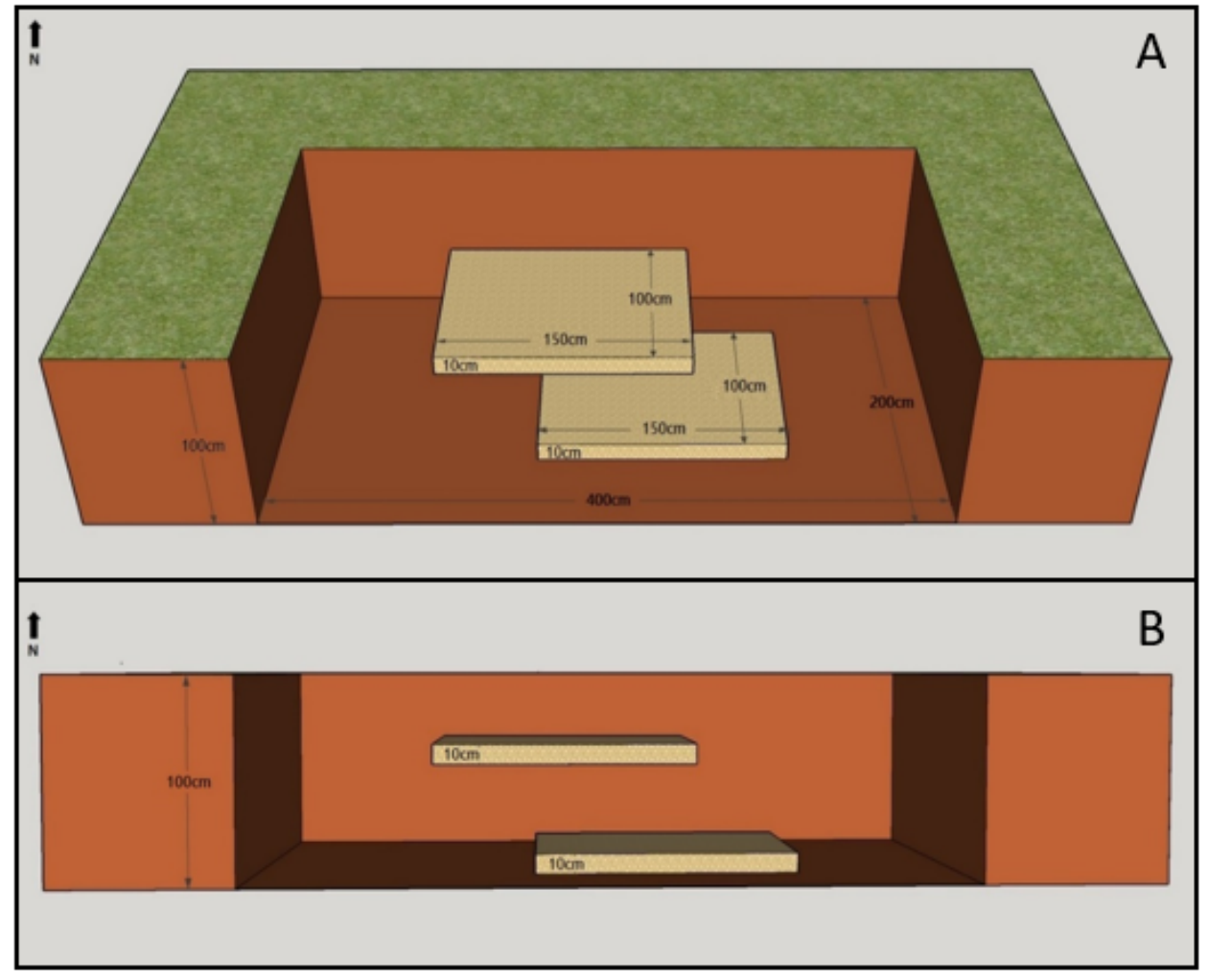

Figure 2. (A) Oblique view of the shell deposits as replicated in Trench 1 and 2. (B) Side view detailing the shell deposits as reproduced in Trench 1 and 2. 
Table 3. Total oyster shell counts for Trench 1 and 2 combined

\begin{tabular}{|l|c|c|c|c|} 
Oyster Shell & $\begin{array}{c}\text { Weight } \\
(\mathrm{kg})\end{array}$ & MNI & NISP & $\begin{array}{c}\text { Volume Dispersed } \\
\left(\mathrm{cm}^{3}\right)\end{array}$ \\
\hline Total & $\mathbf{4 0 6 . 3}$ & $\mathbf{2 8 , 5 3 9}$ & $\mathbf{2 8 , 8 6 4}$ & $\mathbf{2 2 3 , 3 0 0}$
\end{tabular}

Table 4. Gravimetric and volumetric percentages for the field capacity and saturated sediments of Trench 1 and 2.
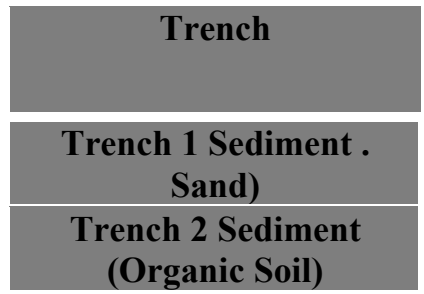

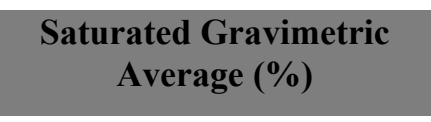

24.2

91.6

\section{Field Capacity Gravimetric Average (\%)}

3.9

42.5

Table 5. Soil water content for GPR surveys (Trench 1).

\begin{tabular}{|c|c|c|}
\hline Depth of Sample & $\begin{array}{c}\text { Gravimetric Wet } \\
(\mathbf{\%})\end{array}$ & $\begin{array}{c}\text { Gravimetric Dry } \\
(\mathbf{\%})\end{array}$ \\
\hline $\mathbf{2 c m}$ & 4.1 & 2.5 \\
\hline $\mathbf{4 0 c m}$ & 4.6 & 3 \\
\hline $\mathbf{8 0 c m}$ & 4.2 & 3.6 \\
\hline $\begin{array}{c}\text { Overall Average for } \\
\text { Trench 1 }\end{array}$ & $\mathbf{4 . 3}$ & $\mathbf{3}$ \\
\hline
\end{tabular}

Table 6. Soil water content for electrical resistivity surveys (Trench 2).

\begin{tabular}{|c|c|c|}
\hline Depth of Sample & $\begin{array}{c}\text { Gravimetric Wet } \\
(\mathbf{\%})\end{array}$ & $\begin{array}{c}\text { Gravimetric Dry } \\
(\mathbf{\%})\end{array}$ \\
\hline $\mathbf{2 c m}$ & 41 & 14.5 \\
\hline $\mathbf{4 0 c m}$ & 42 & 18.5 \\
\hline $\mathbf{8 0 c m}$ & 42.6 & 21.5 \\
\hline $\begin{array}{c}\text { Overall Average for } \\
\text { Trench 2 }\end{array}$ & $\mathbf{4 1 . 8}$ & $\mathbf{1 8 . 1}$ \\
\hline
\end{tabular}




\subsection{GPR Survey}

GPR lines were run with a line spacing of $25 \mathrm{~cm}$ for a distance of approximately $6 \mathrm{~m}$. As survey guides, string lines were run every $50 \mathrm{~cm}$. After an initial survey of both trenches, the GPR results for Trench 2 were found to be uninterpretable (discussed below in Section 3.1) and the focus of the GPR surveys was switched to Trench 1 . The wet survey for Trench 1 was completed with a water content slightly above the estimated field capacity for the sand fill. The 'dry' survey was completed with an average water content (for Trench 1) of $3 \%$ (Table 5) which is less than one gravimetric percent difference from the estimated field capacity at 3.9\% (Table 4). However, from the 'wet' to the 'dry' survey this difference represents a $30 \%$ decrease in the average gravimetric water content; from $4.3 \%$ water per $100 \mathrm{~g}$ of soil to $3 \%$.

\subsection{Electrical Resistivity Survey}

Survey lines plus tape measures were laid out for the positioning of electrodes. All survey lines were run with an electrode spacing of $25 \mathrm{~cm}$ and water was applied to the electrodes to reduce contact resistance with the ground. Initial surveying of both trenches found that Trench 1 produced uninterpretable results (discussed below in Section 3.2) and the focus of the electrical resistivity surveys was switched to Trench 2. Trench 1 was surveyed with four lines to confirm that none of the lines would produce interpretable results. Trench 2 was surveyed at a higher resolution with lines every $25 \mathrm{~cm}$, commencing $25 \mathrm{~cm}$ in from the trench wall making a total of 7 lines. The wet survey for Trench 2 was run with an average gravimetric water content (41.8\%) close to the estimated field capacity (42.5\%) for that matrix (Tables 4 and 6 ). The dry survey was conducted with an average gravimetric water content of $18.1 \%$ which represents a $56 \%$ decrease in gravimetric water content from the wet survey.

\subsection{Data Processing}

\subsubsection{GPR Processing}

GPR survey data were processed in Reflexw. The following processing workflow was employed: subtract mean (or dewow), static correction, manual gain (y), background removal, a bandpass filter (butterworth). Then a time-depth conversion was completed based on a hyperbola (or velocity) adaption. GPR results were topographically corrected in Reflexw based on georeferencing data produced in ESRI ArcMap 10.2.2. Once the survey data were fully processed, the boundaries of the buried shell deposit were identified in the results based on the existence of a distinct reflection in the profiles at the known location of the shell deposit. Both the top and bottom of this reflection was marked every c. $25 \mathrm{~cm}$ using the 'pick' function in Reflexw which allows for isolation of specific points in the profile and the exportation of these points as three space coordinates in ASCII-format. These 'picks' were exported to Microsoft Excel where they were assigned georeferenced coordinates based on information generated from ArcMap before being exported to ArcScene 10.2.2 for the creation of volume estimates and 3D models.

\subsubsection{Electrical Resistivity Processing}

The electrical resistivity files were initially inverted and viewed in the field before being fully processed with AGI EarthImager software. The resistivity files were edited for noisy data points and bad electrodes, which were removed in order to improve the inversion results. The settings employed for this research consisted of standard initial settings as recommended by Advanced Geosciences, Inc. (2009:54-57), then two different sets of resistivity inversion settings. 
The first inversion settings employed were to compensate for the large errors encountered in the Trench 1 survey results. Settings employed are the suggested settings for processing noisy data in the EarthImager2D manual (Advanced Geosciences, Inc. 2009:62-64). These consisted of increasing the acceptable maximum Root Mean Square (RMS) error to 5\% as well as increasing the smoothness and damping factors to 100 to compensate for a large amount of noise in the data. Lastly, the suppress noisy data command was turned on to reduce noise. The second group of inversion settings were tailored to the survey results for Trench 2 . These settings did not utilise the suppress noisy data command and reduced the acceptable RMS error to 3\% and the smoothness and damping factors to 10, which are the standard recommended settings (Advanced Geosciences, Inc. 2009:60-63).

After the inversion, the data were then scaled, so the contour levels were uniform across the different results. A scale range of $1 \Omega-\mathrm{m}$ to $25,000 \Omega-\mathrm{m}$ was chosen as best representing the resistivity values of the shell. The only interpretable electrical resistivity results for isolating the buried shell deposit, were from the organicrich Trench 2. A quantitative method of extracting the shell deposit values from the rest of the inversion results could not be accomplished, so instead the shell deposit was isolated from the processed data via a method similar to the 'pick' system in Reflexw. As there is no 'pick' function in EarthImager2D, this process had to be completed manually. The processed pseudosections were gridded manually over the area of the shell deposit based on the distance markers supplied on the inversion image, then the 'picks' were marked on the image, and the depth and distance were measured off the grid for each 'pick'. 'Picks' were placed on the $25 \mathrm{~cm}$ survey marks where possible, but where the ends of the deposit fell outside the $25 \mathrm{~cm}$ marks, specially georeferenced points were created for them in ArcMap. The electrical resistivity 'picks' were topographically corrected and georeferenced in Microsoft Excel based on information generated in ArcMap 10.2.2, before being saved as CSV files and imported into ArcScene 10.2.2.

\subsubsection{Volume and Three-Dimensional Processing}

To create the 3D models and volume estimations of the buried shell deposit required using both ArcMap and ArcScene. ArcMap was employed to generate accurate topographical information for these trenches as they had initially been located using only global positioning system (GPS) points which have a variable error of $\pm 5 \mathrm{~m}$. To accurately georeference the trenches and survey lines, both were mapped in ArcMap and assigned z values based on dumpy level readings and approximate height above sea-level information. The georeferenced points were then imported into ArcScene and used to create a triangulated irregular network (TIN) of the surface topography of each trench.

The 'picks' created from the GPR and electrical resistivity survey data, which had to be georeferenced in Microsoft Excel based on information generated in ArcMap, were then imported into ArcScene and employed to create a second and third TIN, marking the buried shell deposit boundaries. Volume calculations were created directly from the TINs by using the surface difference tool. Three-Dimensional models (3D polygons) were created using the extrude between tool.

\subsection{Potential Sources of Error}

There are several possible sources of human and system error that could impact the accuracy of the 3D models and volume estimates produced from the geophysical survey data. In the initial collection phase, 
human error is an ever-present possibility. Novice practitioners to the field of geophysics are likely to make a range of mistakes which could affect the data collected to varying degrees. While the system errors produced by the geophysical methods are typically small, this error can be large if compounded by user error during the survey set up and the data processing stages.

The main source of system error introduced to the data during the initial processing is in relating the survey readings back to their real world positions. In electrical resistivity this error can be incorporated into the results during the inversion process, in which the apparent resistivity readings recorded from the field are related back to the true ground resistivity values via inversion modelling. For GPR this can occur during topographic migrations and the conversion of two-way travel-time to depth measurements; during which the processing software accounts for velocity changes in the subsurface that initially resulted in reflections being recorded inaccurately and attempts to adjust these reflections back to their real world positions (cf. Jacob and Urban 2015). If the surveys are run correctly and the data processed correctly these forms of error should be negligible for GPR. When creating volume estimates for a glacier using GPR survey data, Navarro et al. (2014) estimated system error margins for GPR to be in the range of just $4-8 \%$ of the total volume.

Further error, both human and system, can be introduced to the results during the post-processing steps. One source of error is in the interpolation of data between survey lines completed by the software; though with minimal distances between survey lines and detailed topographical survey data these errors should be insignificant. The most significant source of error is likely to come from the visual interpretation of the deposit boundaries in the geophysical results. In order to move the desired data from the GPR and electrical resistivity processing software into the ArcGIS software, a visual interpretation is required in which the user manually marks or 'picks' the shell matrix boundaries. As marking the boundaries is a subjective task it is likely to vary slightly upon replication and is open to misinterpretation of results by the analyst; though by employing a consistent and experienced user there should be minimal differences between interpretations and less error due to incorrect interpretation. While subject to human error, this visual interpretation is still the more accurate method for interpreting survey results as an experienced user is more likely to be able to accurately follow a deposit boundary and distinguish it from noise than the current quantitative systems.

\section{Results}

The different types of fill used in Trenches 1 and 2 had a marked effect on both the GPR and electrical resistivity results.

\subsection{Ground-Penetrating Radar}

While the sand fill of Trench 1 successfully produced interpretable visualisations of the buried shell deposit, the organic fill of Trench 2 obscured the deposit (see Figure 3). The organic-rich fill had the adverse effect of raising the electrical conductivity levels, which caused the radar waves to quickly attenuate and the GPR results to be rendered uninterpretable. 


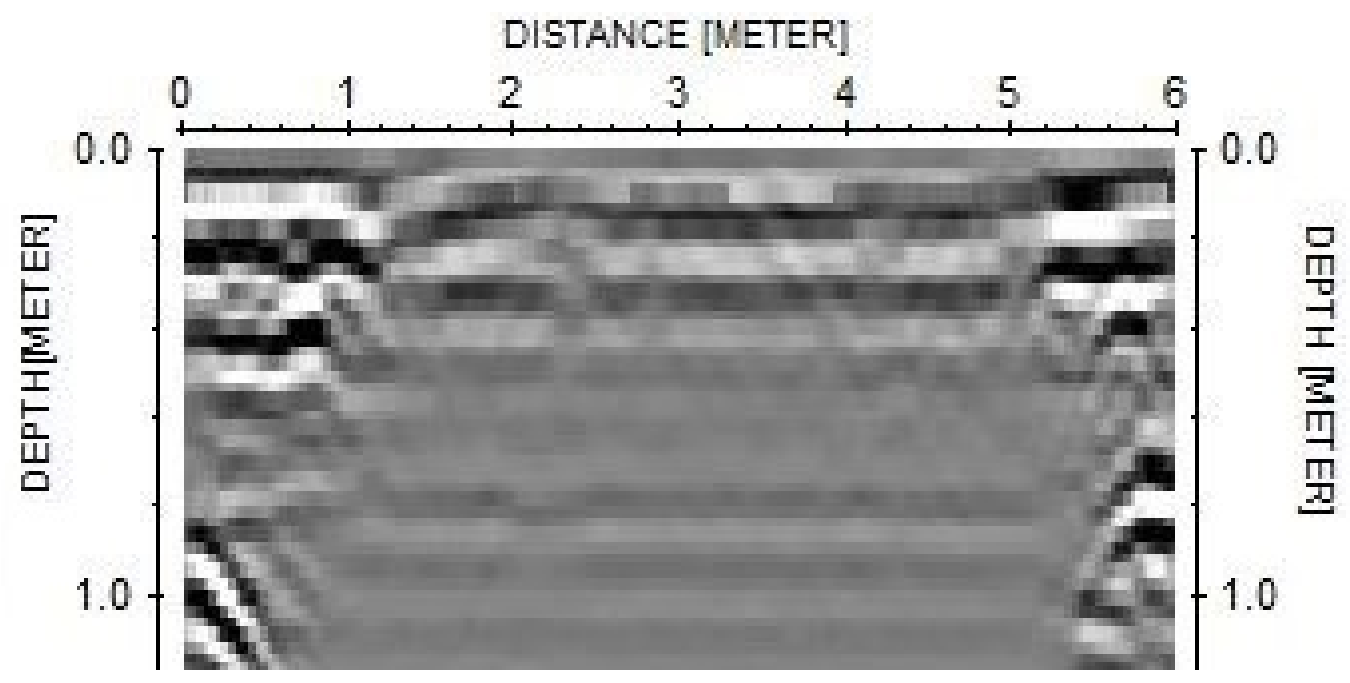

Figure 3. Line 5 of the GPR survey of Trench 2 showing the edges of the trench and then the fill obscuring everything in the trench and beneath it; though the bottom corners of the trench can still be seen at around $1 \mathrm{~m}$ depth on either side of the profile.

\subsubsection{Wet Survey Results}

In the wet survey results the edges of Trench 1 can be observed at $1 \mathrm{~m}$ and at $5 \mathrm{~m}$ across the profile, with the corners at the base of the trench observable at approximately $1 \mathrm{~m}$ in depth (Figure 4). The lower layer of shell deposit is indiscernible from the base of the trench, but the upper layer of the buried shell matrix appears as a planar reflection response located in the middle of the GPR profile (Figure 4). The deposit can be observed starting at a depth of approximately $40 \mathrm{~cm}$ and continuing to around $50 \mathrm{~cm}$.

Lines 1 and 8 were situated close to the trench walls, beneath which there was no shell deposit. The profiles for Lines 1 and 8 illustrate this, with only the top of the trench showing up along the surface and the slightest response from the base of the trench at $1 \mathrm{~m}$. The reflection response representing the shell deposit is observable from Lines 2 to 7 . The lines were interpreted with reference to their adjacent lines so even though Lines 2 and 7 exhibited less distinctive reflections than other lines they still had reflections that related to the more distinctive results in Lines 3 and 6 (Figure 4). Line 4 displayed multiple reflections (or multiples), these were not included in the 'picked' deposit as they were visually identifiable as multiples and not an actual representation of the subsurface; the upper deposit boundary for Line 4 was then 'picked' with reference to Lines 3 and 5. The top and bottom boundaries of the deposit for each profile were 'picked' separately and imported into ArcScene as separate files (Figure 5). 

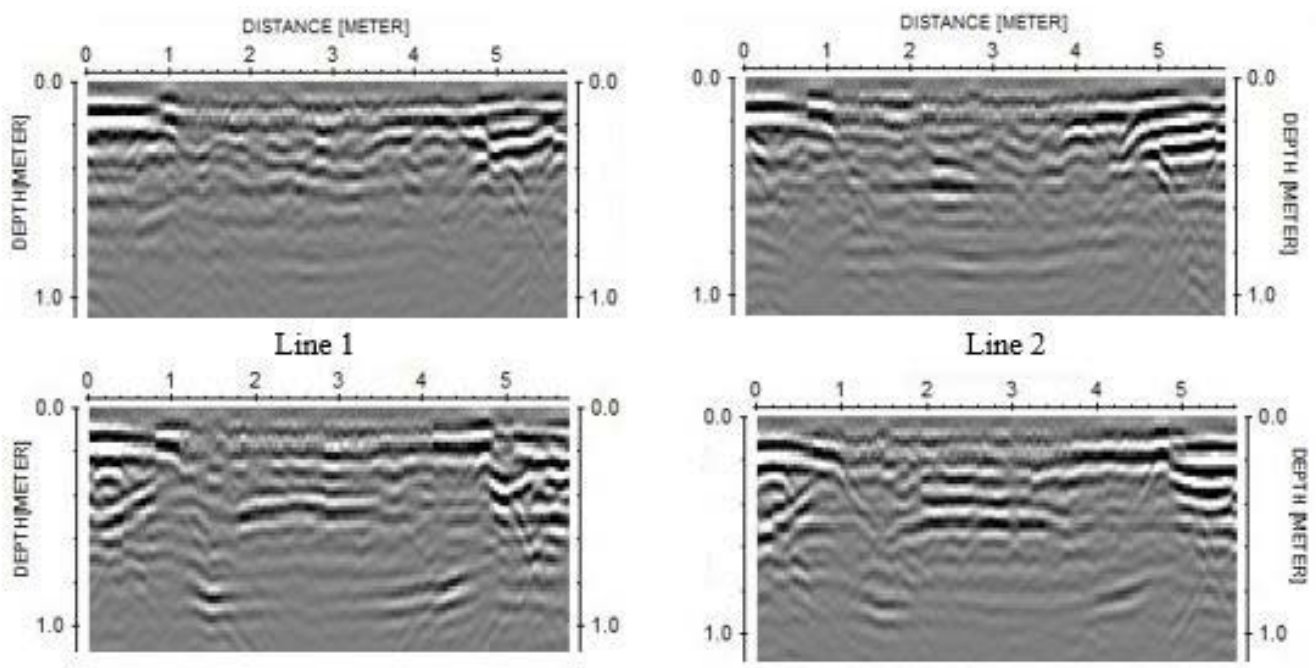

Line 3
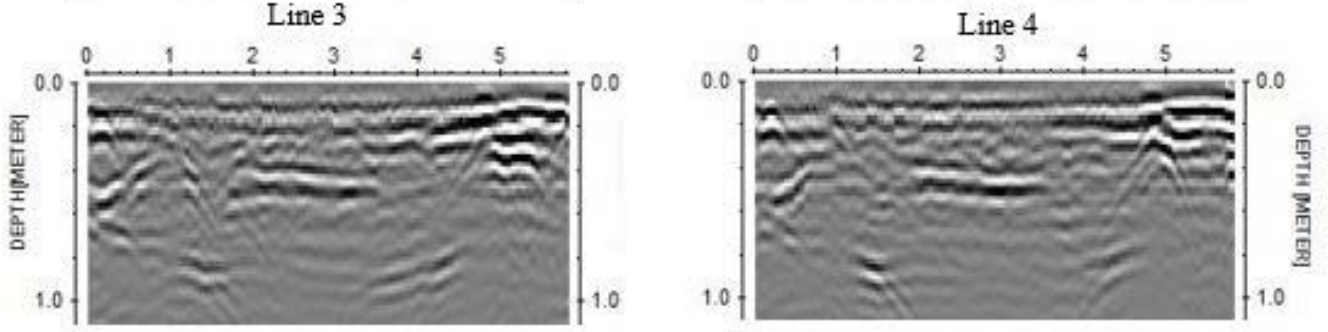

Line 5

Line 6
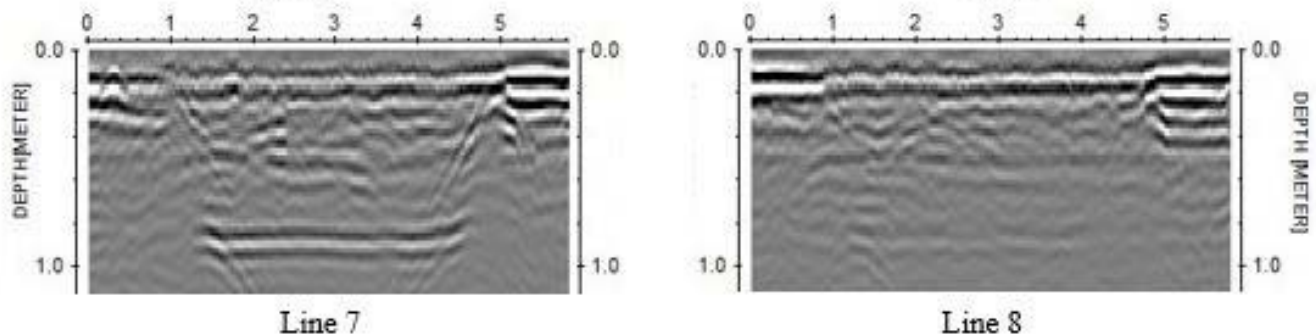

Figure 4. GPR wet survey lines 1 to 8, Trench 1. 


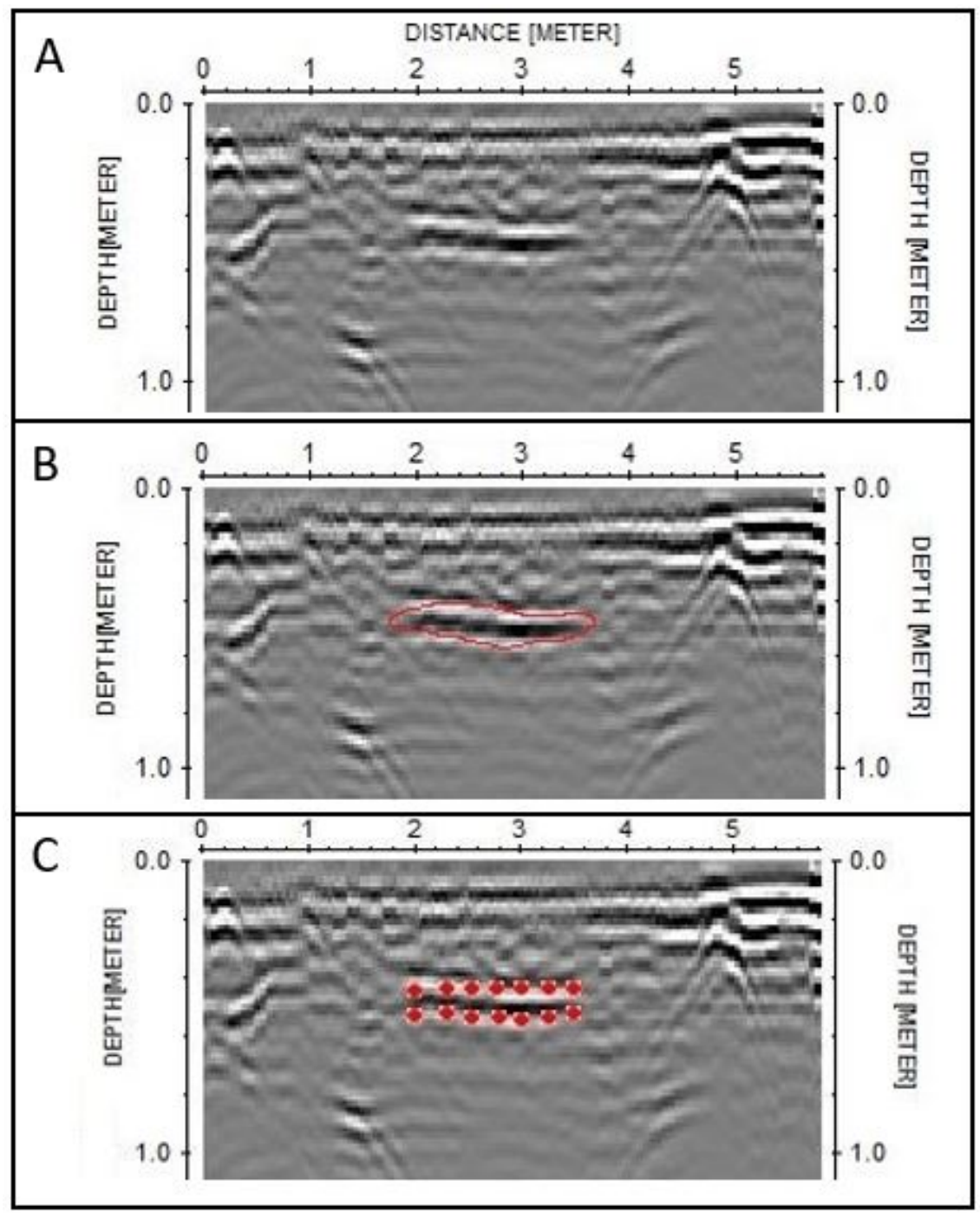

Figure 5. GPR wet survey Line 6, Trench 1. (A) Un-interpreted line, (B) Interpreted shell deposit circled in red, (C) Picks marked in red. 


\subsubsection{Dry Survey Results}

The dry survey results were similar to the wet results, though they were slightly more visually distinctive (Figure 6). The dry survey results were interpreted and 'picked' in the same manner as the wet results, though now Line 7 was considered to be uninterpretable even with reference to Line 6 .

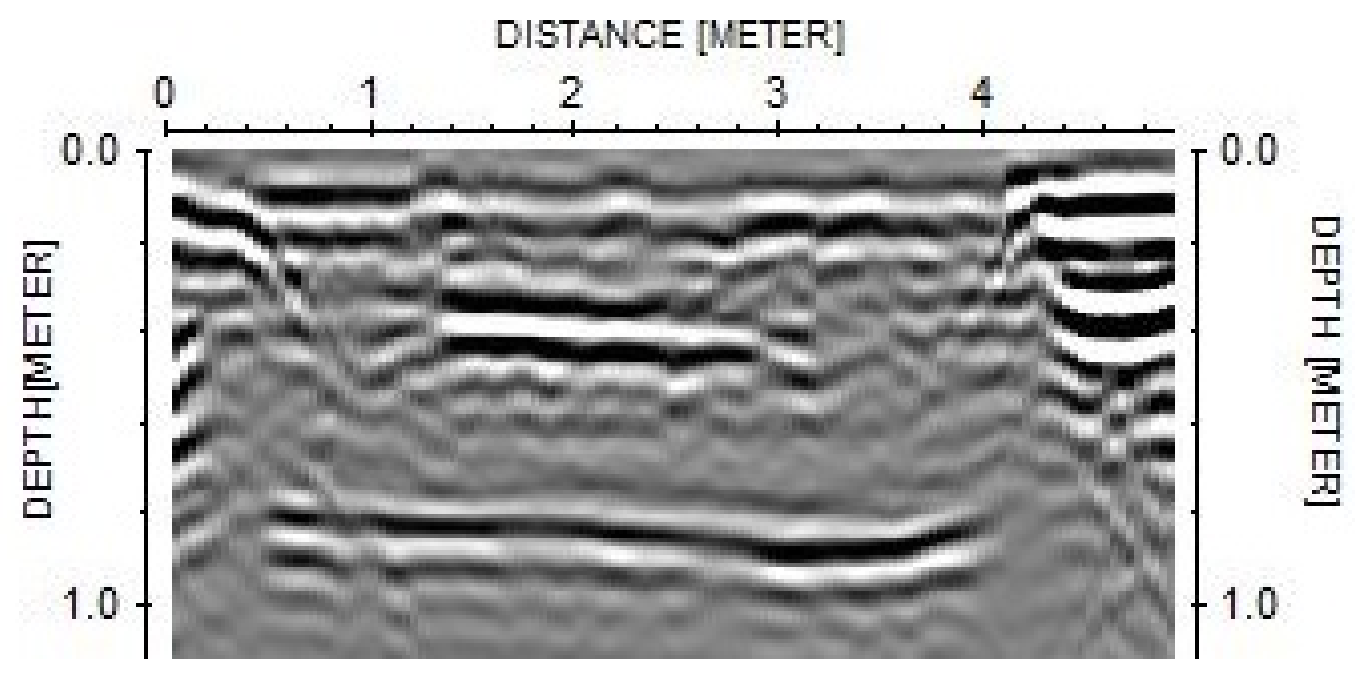

Figure 6. GPR dry survey Line 4, Trench 1.

\subsection{Electrical Resistivity}

The electrical resistivity results for Trenches 1 and 2 varied considerably. As mentioned above, the results for Trench 1 found the sand and shell indistinguishable. The organic fill of Trench 2 provided a conductive medium for the electrical resistivity results making the shell distinguishable from the surrounding sediment. While the results for Trench 1 did not produce an interpretable difference between the shell and sand, the vague shape of the Trench itself is visible in the results (as the higher resistance region between $0.75 \mathrm{~m}$ and $5.50 \mathrm{~m}$ to a depth of $1 \mathrm{~m}$ ) compared to the more conductive clay around it (Figure 7). The ground surface is reading as a more conductive area due to the water poured onto the electrodes to reduce contact resistance.

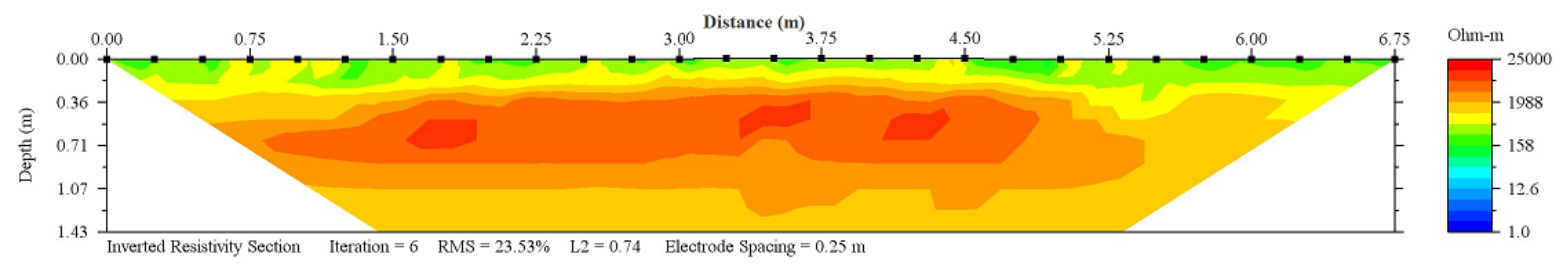

Figure 7. Electrical resistivity results for Line 1 from Trench 1 showing the highly resistive shell matrix of the trench. 


\subsubsection{Wet Survey Results}

Trench 2 appears in the pseudosections as a conductive region surrounded by the more resistive clay; a reverse of the Trench 1 results. Within the trench area, a more resistive patch is visible, representing the upper shell deposit, the lower deposit is indistinguishable from the clay (Figure 8). The pseudosections for Lines 1 and 7, the first and last lines, show patches of resistance due to their proximity to the trench wall, these areas are unrelated to the shell deposit, and the choice was made to disregard them as a by-product of the experimental setup. Small areas of resistance in Lines 2 and 6 were mapped as being part of the shell matrix. They were included because they related to areas of resistance mapped as shell in the adjacent lines.

The region of resistance indicating the shell deposit is comprised of two visually distinct levels of resistance; one at around $158 \Omega-\mathrm{m}$ in bright green and one at around $50 \Omega-\mathrm{m}$ indicated by an aqua colour. As it is open to interpretation whether only the areas of highest resistance indicate the shell deposit and should be 'picked' or

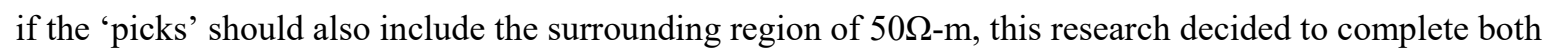
interpretation methods and compare them. Interpretation Method 1 'picks' only the region of higher

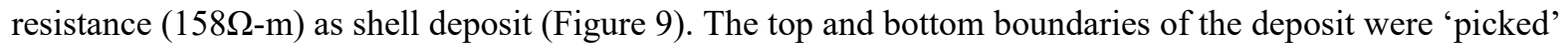
separately and then imported into ArcScene as separate files. For Interpretation Method 2, the entire area of

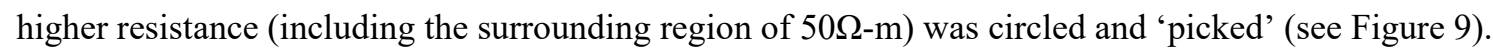



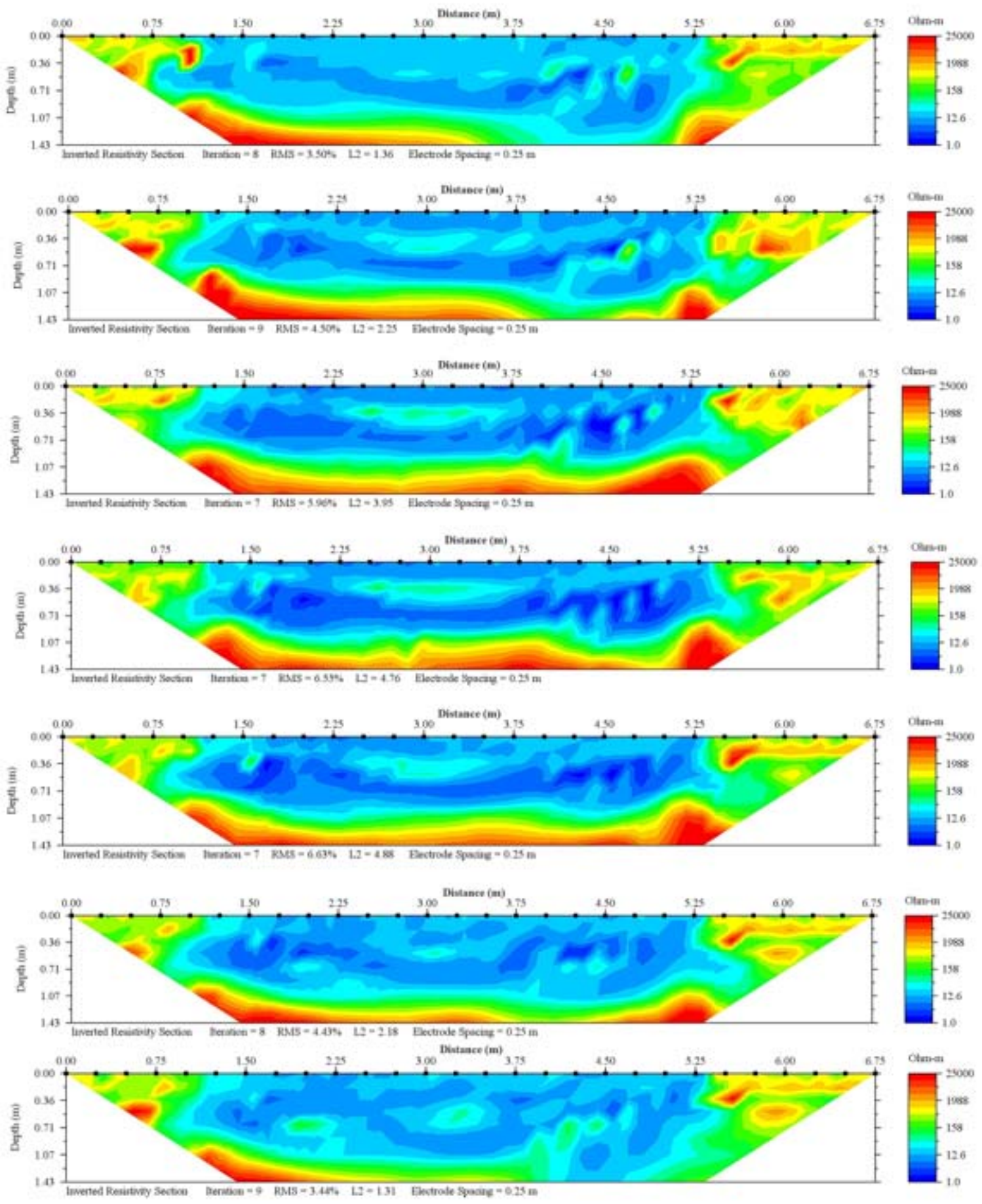

Figure 8. Electrical resistivity wet survey Lines 1 (top) to 7 (bottom) of Trench 2. 


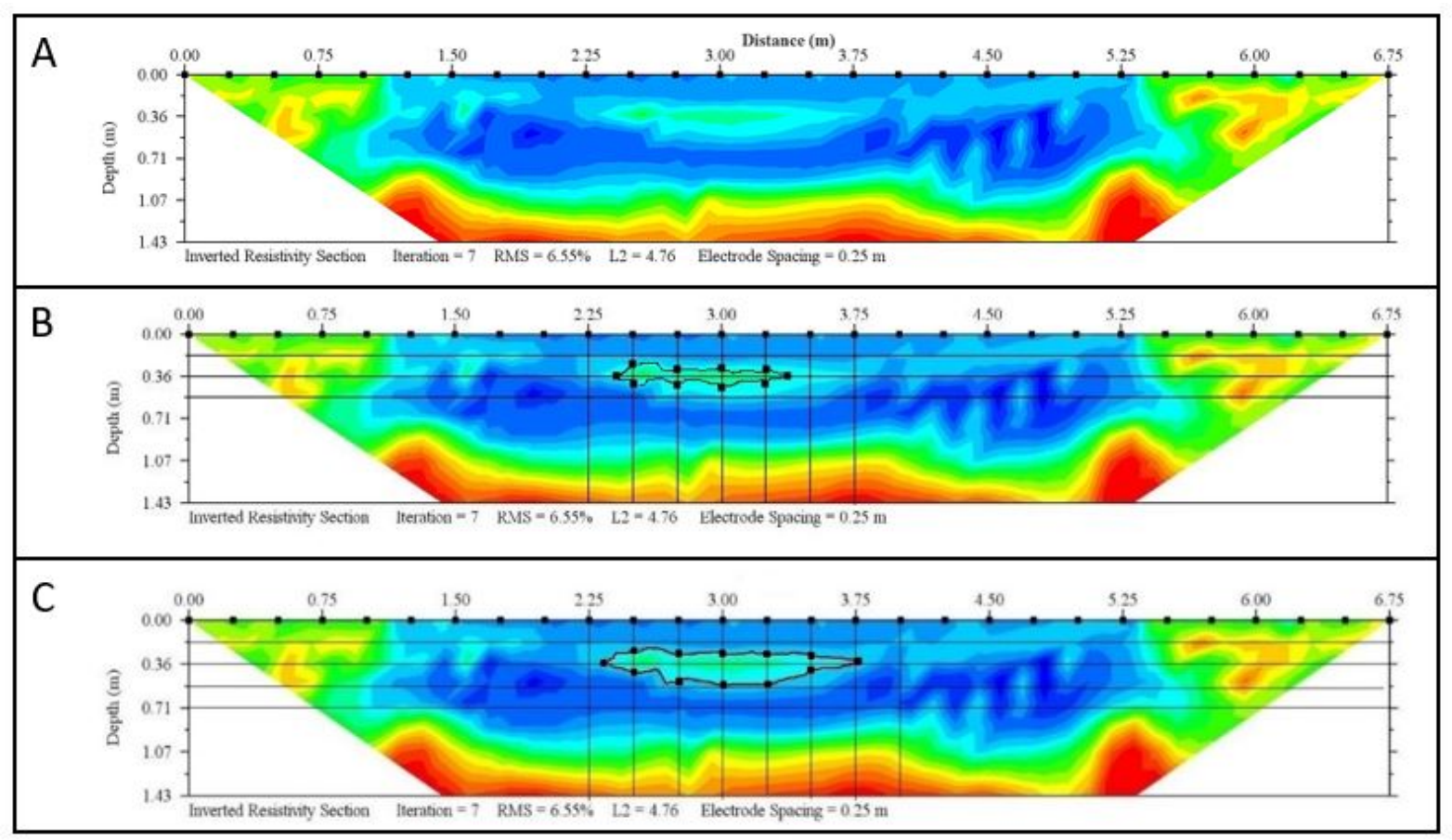

Figure 9. Electrical resistivity wet survey Line 4. (A) Un-picked Line 4, (B) Region of higher resistance identified for Interpretation Method 1 is circled in black with picks marked by black squares, (C) Larger area of resistance identified for Interpretation Method 2 is circled in black with picks marked by black squares.

\subsubsection{Dry Survey Results}

The dry survey results for Trench 2 varied markedly from the wet survey (Figure 10). The ground was significantly drier, and this caused more contact resistance issues. Fresh water was applied to the electrodes instead of salt water to replicate the initial survey methods used during the wet survey. This was originally done to prevent excess salt levels affecting the GPR results but became irrelevant when it was discovered that the organic mix was already too conductive for the radar waves, leading to their dissipation. The method was retained, however, in order to replicate the initial survey methods. The dry sediment, even with the application of water to the electrodes, was highly resistive and contact errors were encountered during the recording of some of the lines though RMS percentages were still low.

Like the wet survey results, patches of resistance in Line 7 were disregarded due to the proximity of the trench wall, though Line 1 no longer exhibited these areas of higher resistance. The small areas of resistance in Lines 2 and 6 were once again mapped as part of the shell matrix because of their relation to areas of resistance in Lines 3 and 5. Like the wet survey results, Interpretation Method 1 'picked' only the areas of highest resistance (Figure 10) while Interpretation Method 2 'picked' the surrounding higher resistance area as well (Figure 10). The resistance values differed from the wet survey results, now registering as about $2,000 \Omega-\mathrm{m}$ instead of $158 \Omega-\mathrm{m}$ with the surrounding area at around $1,000 \Omega-\mathrm{m}$ instead of $50 \Omega-\mathrm{m}$. 


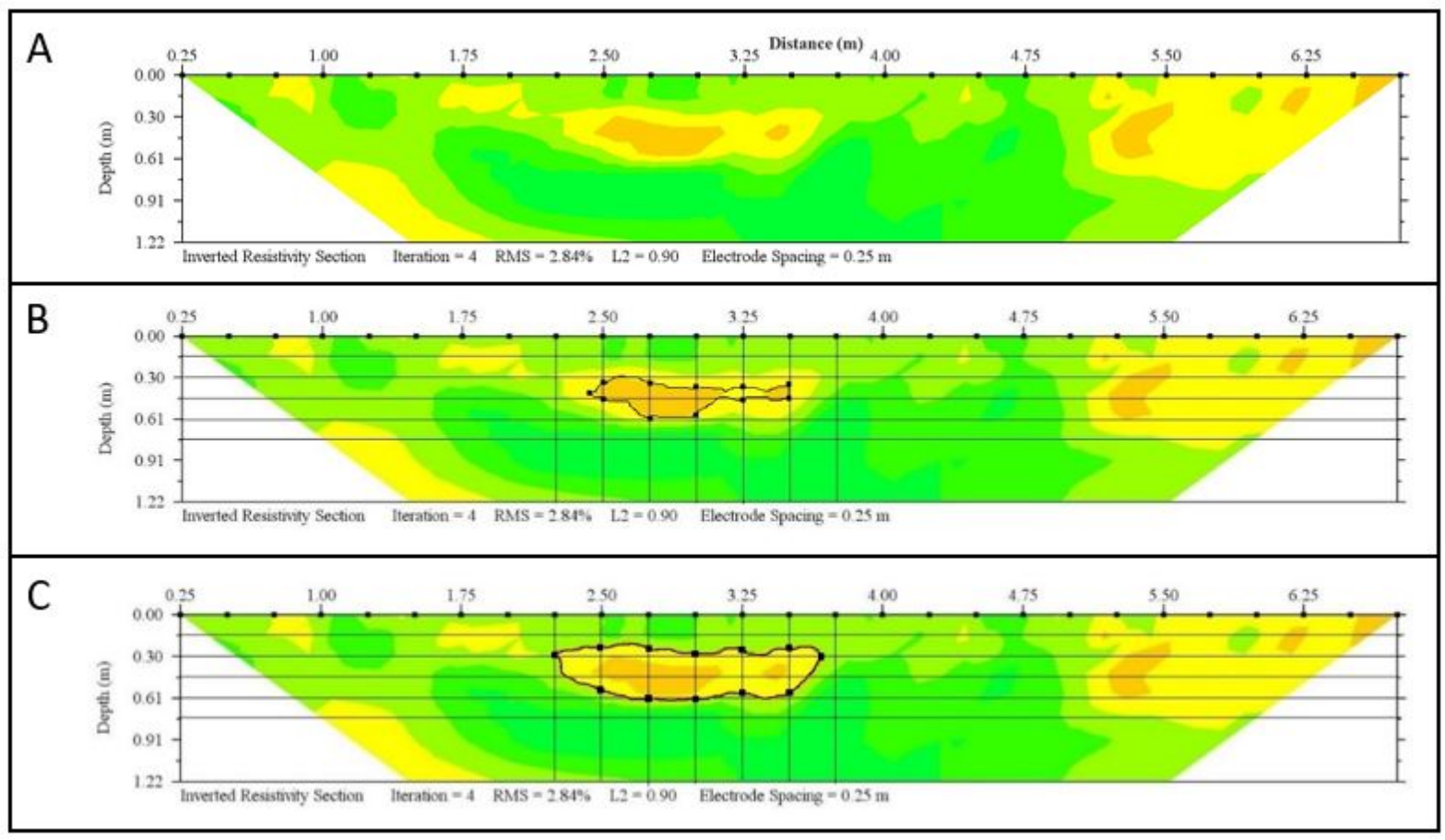

Figure 10. Electrical resistivity dry survey Line 4. (A) Un-picked Line 4, (B) Region of higher resistance identified for Interpretation Method 1 is circled in black with picks marked by black squares, (C) Larger area of resistance identified for Interpretation Method 2 is circled in black with picks marked by black squares.

\section{Three-Dimensional Mapping and Volume Results}

By mapping the 'picks' for Trench 1 and 2 into ArcScene, 3D models of the buried shell deposits were created. The 3D models based on the GPR results for Trench 1 are depicted in Figure 11. The electrical resistivity results for Trench 2, both Interpretation Method 1 and 2, are shown in Figure 12.

Volume estimates were also calculated from ArcScene (Table 7). These geophysical volume estimates were compared to the volume of the area the shell occupied when deposited $\left(0.15 \mathrm{~m}^{3}\right)$ and from this comparison an error percentage for the geophysical volume estimate was created (Equation 2).

$\%$ error $=([$ actual value - experimental value $] /$ actual value $) \times 100$

(Equation 2)

The shell matrix volume for Trench 1, based on the GPR results, was calculated to be $0.19 \mathrm{~m}^{3}$ from the wet survey results and $0.16 \mathrm{~m}^{3}$ from the dry survey. The total for Trench 2, based on the electrical resistivity Interpretation Method 1 'picks', was $0.19 \mathrm{~m}^{3}$ for the wet survey and $0.11 \mathrm{~m}^{3}$ for the dry survey. While Interpretation Method 2 'picks' produced estimates of $0.32 \mathrm{~m}^{3}$ for the wet and $0.17 \mathrm{~m}^{3}$ for the dry survey. With the exception of the Interpretation Method 1 dry survey volume estimate (which was a $26 \%$ underestimate), all the volume results overestimated the shell deposit compared to the actual space taken up by the deposit in-ground. 
As transect spacing is considered an impacting factor on the results of geophysical survey the final variable tested was line spacing; with these initial results (based on the more ideal $25 \mathrm{~cm}$ spacing) compared to results produced by a survey with $50 \mathrm{~cm}$ transect spacing. To create these $50 \mathrm{~cm}$ survey results, every other survey line was removed from the processing. For the electrical resistivity only Lines 2, 4 and 6 now contributed to the modelled results while for the GPR, Lines 2, 4, 6 and 8 were used (though Line 8 had no shell deposit and did not contribute to the modelled results). These new results were then used to produce both 3D models (Figures 13 and 14) and volume estimates of the deposit (Table 8).

The volume estimate results produced from the $50 \mathrm{~cm}$ survey vary significantly from those produced from the $25 \mathrm{~cm}$ survey. The GPR volume estimates now closely match the in-ground deposit values; with the wet survey returning an estimate of $0.15 \mathrm{~m}^{3}$ matching the actual deposit and dry survey results at $0.14 \mathrm{~m}^{3}$ just slightly underestimating the deposit. Meanwhile, the electrical resistivity results significantly underestimate the volume of the deposit for Interpretation Method 1 and drop from an $113 \%$ to an $86 \%$ overestimate for the wet survey results of Interpretation Method 2, and from a 13\% overestimate to a 13\% underestimate for the dry survey results.

To create specific confidence intervals for these survey results Equation 3 was used and was calculated for a confidence level of $95 \%$.

$$
\bar{X} \pm t \frac{s}{\sqrt{n}} \quad(\text { Equation 3) }
$$

The error percentages for all the surveys were included (wet and dry, $25 \mathrm{~cm}$ and $50 \mathrm{~cm}$ line spacing) and all confidence intervals presented have been rounded to the nearest $0.5 \%$. The margin of error experienced during surveys for the GPR was $9.5 \% \pm 15.5 \%$, while the electrical resistivity was $44.5 \% \pm 31.5 \%$ for Interpretation Method 1 and 56 $\pm 70.5 \%$ Interpretation Method 2. The more inclusive upper range of these error margins ( $25 \%, 76 \%$ and $126.5 \%$ respectively) will be applied as the more accurate error margin for the volume results. Meaning the actual volume results for the total shell deposit should fall within $\pm 25 \%$ of the estimated volume produced from the GPR survey results (i.e. if looking at the wet survey results for the GPR the actual shell volume should fall within $0.19 \mathrm{~m}^{3} \pm 0.04 \mathrm{~m}^{3}$ ). While for electrical resistivity results the actual shell volume should fall within $\pm 76 \%$ of the estimated volume for Interpretation Method 1 and $\pm 126.5 \%$ for Interpretation Method 2. 


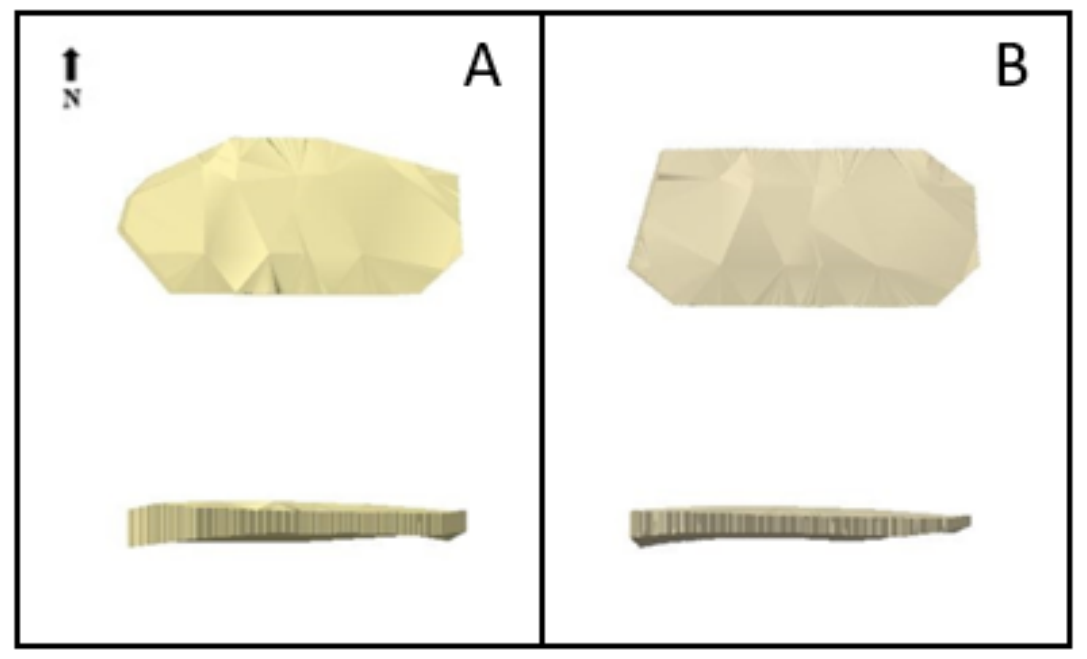

Figure 11. Top and side view of shell matrix deposits for Trench 1 GPR results as modelled from (A) wet survey results and (B) dry survey results.

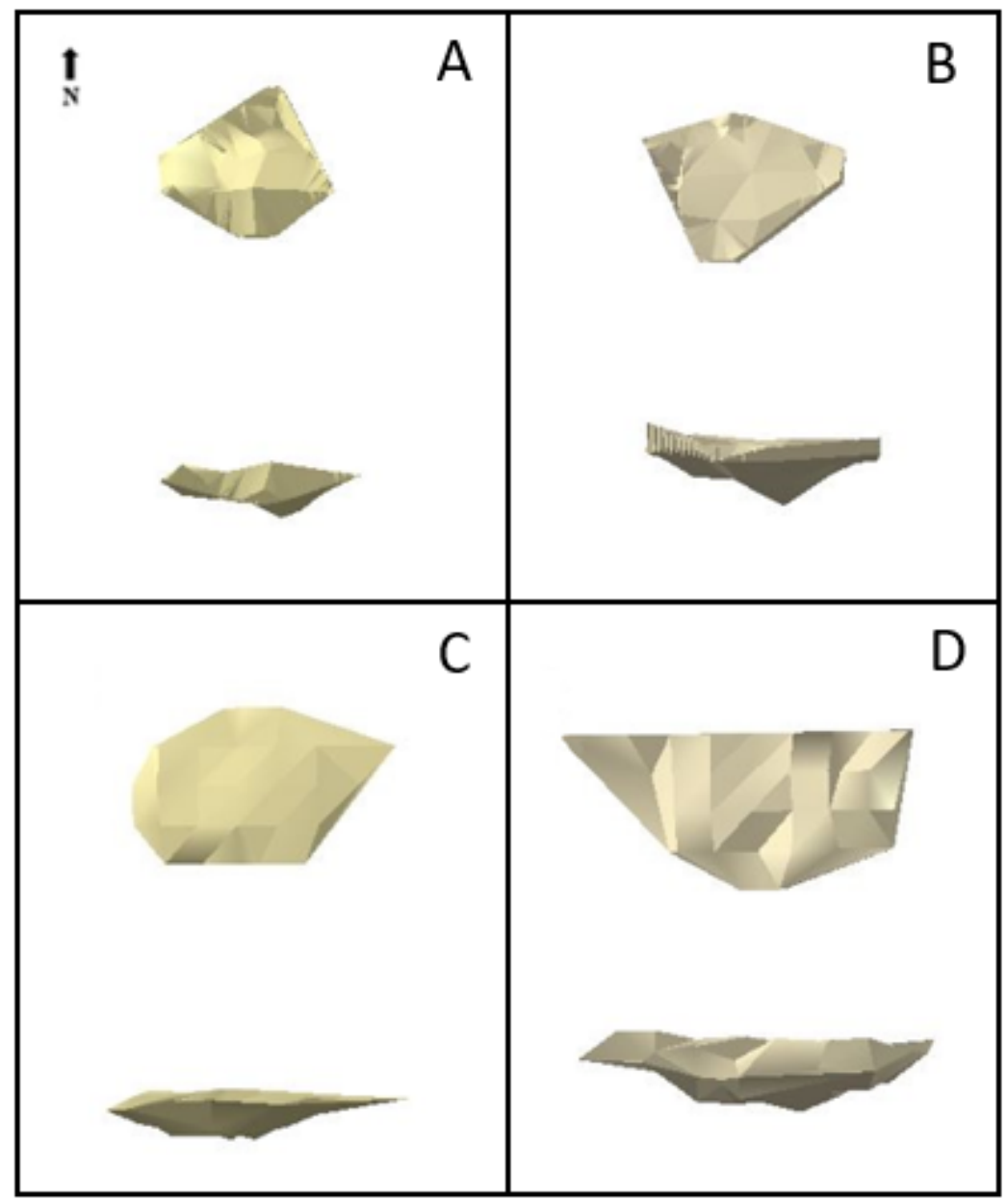

Figure 12. View of the top and sides of Trench 2 shell matrix deposits from electrical resistivity processing. (A) Interpretation Method 1 wet survey results (B) Interpretation Method 1 dry survey results, (C) Interpretation Method 2 wet survey results (D) Interpretation Method 2 dry survey results. 


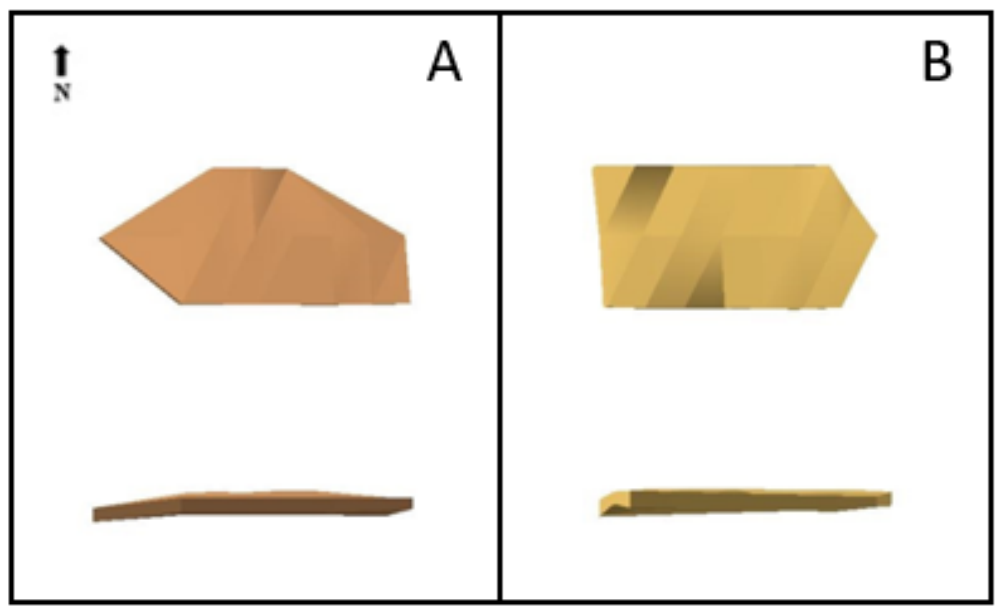

Figure 13. Top and side view of shell matrix deposits for Trench $1 \mathrm{GPR}$ results as modelled from $50 \mathrm{~cm}$ transect spacing (A) wet survey results and (B) dry survey results.

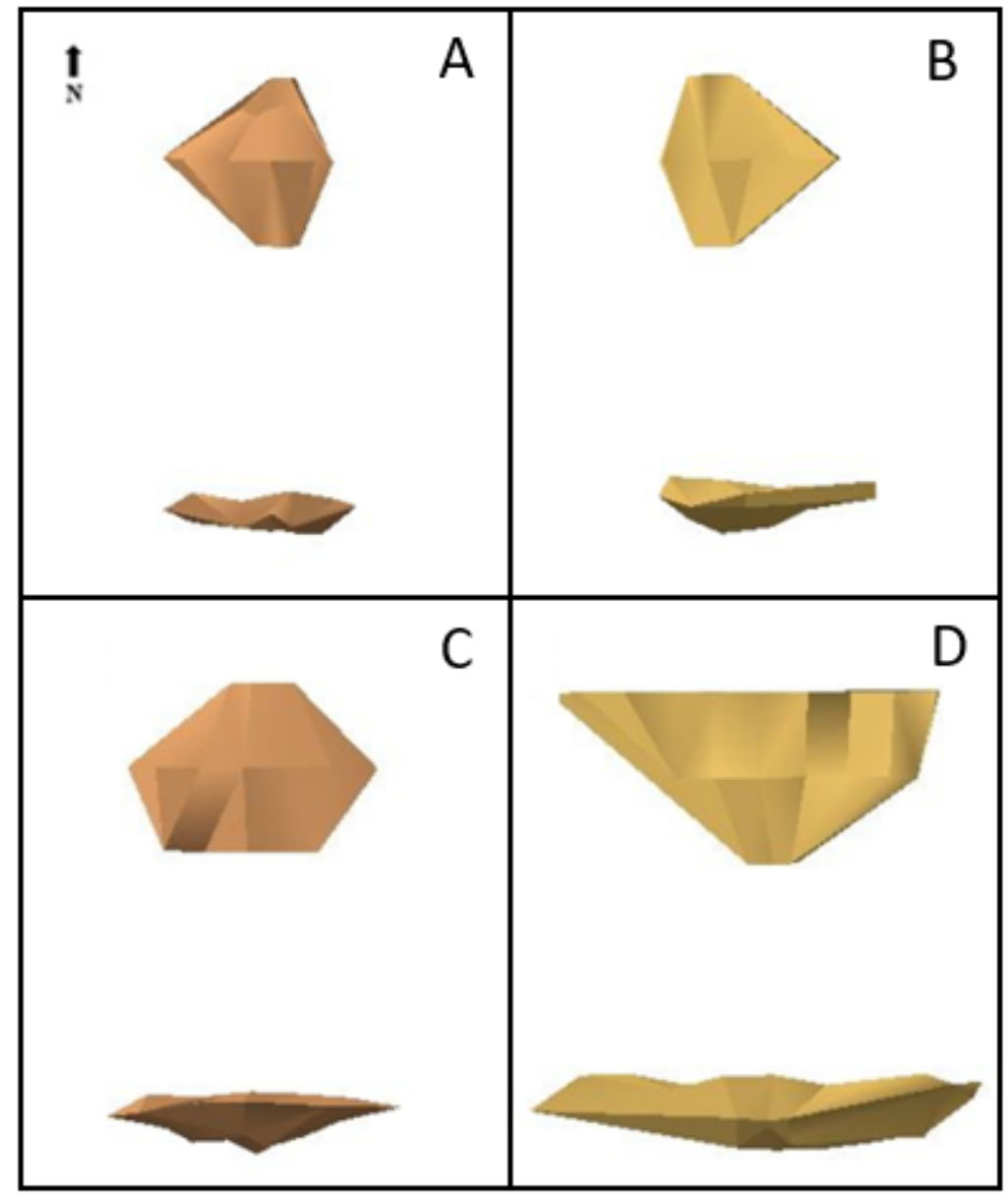

Figure 14. View of the top and sides of Trench 2 shell matrix deposits from electrical resistivity processing for $50 \mathrm{~cm}$ transect spacing. (A) Interpretation Method 1 wet survey results (B) Interpretation Method 1 dry survey results, (C) Interpretation Method 2 wet survey results (D) Interpretation Method 2 dry survey results. 
Table 7. Trench 1 and 2 volume calculation results compared to the volume of shell placed in the ground; for survey lines at $25 \mathrm{~cm}$.

\begin{tabular}{|c|c|c|c|c|}
\hline $\begin{array}{c}\text { Experimental } \\
\text { Trench }\end{array}$ & $\begin{array}{l}\text { Shell Matrix } \\
\text { Volume }\left(\mathrm{m}^{3}\right) \\
\text { Based on } \\
\text { Geophysical } \\
\text { Survey Results }\end{array}$ & $\begin{array}{c}\text { Shell Matrix } \\
\text { Volume }\left(\mathrm{m}^{3}\right) \\
\text { Based on Size of } \\
\text { Shell Deposit Placed } \\
\text { in the Ground }\end{array}$ & $\begin{array}{l}\text { Modelling } \\
\text { Compared to } \\
\text { Ground } \\
\text { Truthed } \\
\text { Volume }\left(\mathrm{m}^{3}\right)\end{array}$ & $\begin{array}{l}\text { Error } \\
\text { Percentage }\end{array}$ \\
\hline $\begin{array}{c}\text { Trench } 1 \\
\text { (GPR) } \\
\text { Wet }\end{array}$ & 0.19 & 0.15 & +0.04 & $\begin{array}{c}26 \% \\
\text { (Overestimate) }\end{array}$ \\
\hline $\begin{array}{c}\text { Trench } 1 \\
\text { (GPR) } \\
\text { Dry }\end{array}$ & 0.16 & 0.15 & +0.01 & $\begin{array}{c}6 \% \\
\text { (Overestimate) }\end{array}$ \\
\hline $\begin{array}{c}\text { Trench } 2 \\
\text { Interpretation } \\
\text { Method } 1 \\
\text { (ER) Wet }\end{array}$ & 0.19 & 0.15 & +0.04 & $\begin{array}{c}26 \% \\
\text { (Overestimate) }\end{array}$ \\
\hline $\begin{array}{c}\text { Trench } 2 \\
\text { Interpretation } \\
\text { Method } 1 \\
\text { (ER)Dry }\end{array}$ & 0.11 & 0.15 & -0.04 & $\begin{array}{c}26 \% \\
\text { (Underestimate) }\end{array}$ \\
\hline $\begin{array}{l}\text { Trench } 2 \\
\text { Interpretation } \\
\text { Method } 2 \\
\text { (ER)Wet }\end{array}$ & 0.32 & 0.15 & +0.17 & $\begin{array}{c}113 \% \\
\text { (Overestimate) }\end{array}$ \\
\hline $\begin{array}{c}\text { Trench } 2 \\
\text { Interpretation } \\
\text { Method } 2 \\
\text { (ER)Dry }\end{array}$ & 0.17 & 0.15 & +0.02 & $\begin{array}{c}13 \% \\
\text { (Overestimate) }\end{array}$ \\
\hline
\end{tabular}


Table 8. Trench 1 and 2 volume calculation results compared to the volume of shell placed in the ground; for survey lines at $50 \mathrm{~cm}$.

\begin{tabular}{|c|c|c|c|c|}
\hline $\begin{array}{c}\text { Experimental } \\
\text { Trench }\end{array}$ & $\begin{array}{l}\text { Shell Matrix } \\
\text { Volume }\left(\mathrm{m}^{3}\right) \\
\text { Based on } \\
\text { Geophysical } \\
\text { Survey Results }\end{array}$ & $\begin{array}{c}\text { Shell Matrix } \\
\text { Volume }\left(\mathrm{m}^{3}\right) \\
\text { Based on Size of } \\
\text { Shell Deposit Placed } \\
\text { in the Ground }\end{array}$ & $\begin{array}{l}\text { Modelling } \\
\text { Compared } \\
\text { to Ground } \\
\text { Truthed } \\
\text { Volume }\left(\mathbf{m}^{3}\right)\end{array}$ & $\begin{array}{c}\text { Error } \\
\text { Percentage }\end{array}$ \\
\hline $\begin{array}{c}\text { Trench } 1 \text { (GPR) } \\
\text { Wet }\end{array}$ & 0.15 & 0.15 & 0.00 & $0 \%$ \\
\hline $\begin{array}{c}\text { Trench } 1 \text { (GPR) } \\
\text { Dry }\end{array}$ & 0.14 & 0.15 & -0.01 & $\begin{array}{c}6 \% \\
\text { (Underestimate) }\end{array}$ \\
\hline $\begin{array}{c}\text { Trench } 2 \\
\text { Interpretation } \\
\text { Method } 1 \text { (ER) } \\
\text { Wet }\end{array}$ & 0.04 & 0.15 & -0.11 & $\begin{array}{c}73 \% \\
\text { (Underestimate) }\end{array}$ \\
\hline $\begin{array}{c}\text { Trench } 2 \\
\text { Interpretation } \\
\text { Method } 1 \text { (ER) } \\
\text { Dry }\end{array}$ & 0.07 & 0.15 & -0.08 & $\begin{array}{c}53 \% \\
\text { (Underestimate) }\end{array}$ \\
\hline $\begin{array}{c}\text { Trench } 2 \\
\text { Interpretation } \\
\text { Method } 2 \text { (ER) } \\
\text { Wet }\end{array}$ & 0.28 & 0.15 & +0.13 & $\begin{array}{c}86 \% \\
\text { (Overestimate) }\end{array}$ \\
\hline $\begin{array}{c}\text { Trench } 2 \\
\text { Interpretation } \\
\text { Method } 2 \text { (ER) } \\
\text { Dry }\end{array}$ & 0.13 & 0.15 & -0.02 & $\begin{array}{c}13 \% \\
\text { (Underestimate) }\end{array}$ \\
\hline
\end{tabular}

\section{Discussion}

The 3D model of the GPR results for the upper shell deposit fairly accurately represents the shape of the actual in-ground mass for both the wet and dry surveys. However, this changed when the survey lines were reduced to $50 \mathrm{~cm}$ spacing, with the edges of the model becoming distorted. The volume error rates for the GPR surveys showed relatively precise and accurate results $(26 \%, 6 \%, 0 \%$, and $-6 \%)$, except for the one outlier from the wet survey which was a $26 \%$ overestimate. However the lower error percentages for the $50 \mathrm{~cm}$ surveys and $25 \mathrm{~cm}$ dry survey was partially due to Line 7 being left out of the interpretation. For the $25 \mathrm{~cm}$ dry survey, Line 7 was left out because it was considered too difficult to interpret while for the $50 \mathrm{~cm}$ surveys Line 7 fell outside the $50 \mathrm{~cm}$ spacing and was excluded. Thus the precision of the error rates was partially due to the omission of Line 7 from the results, and may have been closer to the $26 \%$ exhibited by the $25 \mathrm{~cm}$ wet survey results were it included. As Line 7 represented the boundary of the shell deposit it illustrates how detecting or failing to detect the boundary can have a significant impact on the results.

The electrical resistivity results exhibited less accuracy in both their 3D models and their volume estimates. The 3D models showed significant distortion compared to the actual shell deposit; though where the entire contiguous higher resistance area was circled and 'picked' in Interpretation Method 2 a more accurate, but still distorted, 3D model was created. The volume estimates varied significantly and showed little precision or accuracy $(26 \%,-26 \%, 133 \%, 13 \%,-73 \%,-53 \%, 86 \%$ and $-13 \%)$. Though these results were not 
particularly accurate, the 3D models and volume estimates produced did still provide valuable information about the general size and shape of the buried shell deposit, allowing for a greater understanding of the buried matrix.

The accuracy of the methods varied significantly from GPR to electrical resistivity, in both the production of 3D models and volume estimations. The error produced by the methods is likely to be a by-product of the processing software trying to relate the recorded readings back to their real world positions and the visual interpretation of deposit boundaries in the results by the analyst. The GPR was the more precise and accurate method, as noted in Section 2.5. The system error generated by GPR during processing is fairly low while the reflections produced by the shell deposit in GPR profiles were visually distinct and easy to interpret. Conversely the electrical resistivity averaged out the resistivity values between readings, creating a less distinct boundary for the shell deposit in the results. Where the actual shell deposit boundary occurred in the resistivity results was open to interpretation and so two different methods of interpretation were tested for this study (Interpretation Method 1 and 2). This geophysical method, unsurprisingly, produced both less accurate and less precise results.

The moisture content of the surrounding sediment, as theorised, was found to have a noticeable effect on the geophysical surveys. The GPR survey results were clearer and more easily interpreted under the drier survey conditions producing a better 3D model and more accurate volume estimation. This greater accuracy and higher amplitude response from the shell deposit in the dry survey results was likely due to less radar wave attenuation than that experienced under the more conductive environment of the wet survey. The electrical resistivity survey results were more visually distinct under the wetter and more electrically conductive survey conditions, but like the GPR, they produced more accurate modelled results under the drier ground conditions.

The results of the geophysical surveys for the experimental site varied considerably for each method. The electrical resistivity could not distinguish the resistive shell material from the highly resistive sand, while the GPR showed clear reflections of the upper shell deposit. Conversely, the garden soil mix employed as a proxy for a more conductive environment, allowing for interpretable electrical resistivity data, quickly attenuated the radar waves rendering the GPR data uninterpretable. Neither geophysical method could distinguish the lower shell mass from the clay substrate it lay upon. For the electrical resistivity, the problem appeared to be that the shell and the clay, like the shell and sand, were both highly resistive and too close to differentiate. For the dry survey GPR results, the reflections from the hard-packed clay appear to have obscured any reflections from the small shell mass on top of it, while the wet survey seems to have suffered from attenuation by $1 \mathrm{~m}$ in depth. The upper shell layer probably also helped obscure the lower deposit, though the two layers did not entirely overlap.

\section{Conclusion}

This case study attempted to address sampling issues in archaeological shell matrix research by employing a methodology novel to the field. By utilising GPR and electrical resistivity to survey buried shell deposits and by transforming those survey results into interpretable volume estimates and 3D models, we have demonstrated that geophysical surveys can create information about buried shell deposits that could be employed in creating sampling regimes and in better understanding how excavated samples represent the 
overall site. While both instruments mapped the deposits, on a whole, GPR appears to be the better instrument for generating both volume estimates and 3D models. The electrical resistivity was limited in its accuracy, although the results produced did give some insight into the buried deposit and so it could still represent the more desirable survey method in situations where the site is covered in irremovable vegetation that would hamper a GPR system.

By employing these geophysical methods alongside limited test excavations more nuanced sampling strategies can be created; in which initial excavation can help inform interpretation of the geophysical surveys results which can then, in turn, inform the excavation of where the best locations to place further samples would be. Such a methodology would create a sampling strategy for which a good deal was known about how the samples taken related back to and were representative of the overall site. Not only does this improve sampling in shell matrix research, but in doing so the geophysical survey results are actually generating new knowledge about the site being investigated.

\section{Acknowledgements}

SLK is the recipient of an Australian Postgraduate Award Scholarship. We extend a special thanks to Sarah Slater, Texas Nagel, Robin Twaddle, Christian Reepmeyer, Samantha Aird, Sam Lansdown, Redbird Ferguson, Emma Rehn, Djerami Callope, Alice Buhrich, Tanya Drury, Graeme Cotter, Brian Kenady, Joshua Neilson and the 2013 and 2014 AR3008 classes for assistance in the experimental setup. Thanks to Paul Nelson and Shannon Todd for advice and assistance regarding soil moisture analysis. Thanks to the team from Cairns Ocean Products and the team from Preston Fresh for supplying the oyster shell for the experiment. Lastly we thank Lawrence B. Conyers for comments. SU is the recipient of an Australian Research Council Future Fellowship (project number FT120100656). Work on this paper was undertaken while SU was visiting as an Honorary Fellow in the School of Social Sciences, The University of Western Australia.

\section{References}

Advanced Geosciences, Inc. 2003. Instruction Manual for the MiniStingTM and the SwiftTM. Austin, Texas: Advanced Geosciences, Inc.

Advanced Geosciences, Inc. 2009. Instruction Manual for EarthImager 2D: Resistivity and IP Inversion Software (Version 2.4.0). Austin, Texas: Advanced Geosciences, Inc.

Ai, S., Wang Z, Dongchen E, Hélmen K, Tan Z, Zhou C, Sun W. 2014. Topography, ice thickness and ice volume of the glacier Pedersenbreen in Svalbard, using GPR and GPS. Polar Research 33(1):1-8. http://dx.doi.org/10.3402/polar.v33.18533

Ambrose, W.R. 1967. Archaeology and shell middens. Archaeology and Physical Anthropology in Oceania 2(3):169-187. http://www.jstor.org/stable/40386019

Arias P, Diniz M, Cubas M, Duarte C, Iriarte E, Salzmann C, Teichner F, Teira L. 2017. Looking for the traces of the last huntergatherers: Geophysical survey in the Mesolithic shell middens of the Sado valley (southern Portugal). Quaternary International 435:61-70. https://doi.org/10.1016/j.quaint.2016.02.016 
Arnold JE, Ambos EL, Larson DO. 1997. Geophysical surveys of stratigraphically complex island California sites: New implications for household archaeology. Antiquity 71(271):157-168.

https://doi.org/10.1017/S0003598X00084647

Bailey GN. 1975. The role of molluscs in coastal economies: The results of midden analysis in Australia. Journal of Archaeological Science 2(1):45-62. https://doi.org/10.1016/0305-4403(75)90045-X

Baojuan H, Zhongqin L, Feiteng W, Wenbin W, Puyu W, Kaiming L. 2015. Glacier volume estimation from ice-thickness data, applied to the Muz Taw glacier, Sawir Mountains, China. Environmental Earth Sciences 74(3):1861-1870. https://doi.org/10.1007/s12665-015-4435-2

Bērziņš V, Brinker U, Klein C, Lübke H, Meadows J, Rudzīte M, Schmölcke U, Stümpel H, Zagorska I. 2014. New research at Riņnukalns, a Neolithic freshwater shell midden in northern Latvia. Antiquity 88(341):715-732. https://doi.org/10.1017/S0003598X0005064X

Binder D, Brückl E, Roch KH, Behm M, Schöner W, Hynek B. 2009. Determination of total ice volume and ice-thickness distribution of two glaciers in the Hohe Tauern region, Eastern Alps, from GPR data. Annals of Glaciology 50(51):71-79. https://doi.org/10.3189/172756409789097522

Bowdler S. 2014. Shell middens and mollusks. In J. Balme and A. Paterson (eds), Archaeology in Practice: A Student Guide to Archaeological Analyses (2), pp.361-384. Chichester, West Sussex: John Wiley \& Sons, Inc.

Chadwick WJ, Madsen JA. 2000. The application of ground-penetrating radar to a coastal prehistoric archaeological site, Cape Henlopen, Delaware, USA. Geoarchaeology 15(8):765-781. https://doi.org/10.1002/1520-6548(200012)15:8<765::AID-GEA2>3.0.CO;2-H

Claassen C. 1998. Shells. New York: Cambridge University Press.

Colucci RR, Forte E, Boccali C, Dossi M, Lanza L, Pipan M, Guglielmin M. 2015. Evaluation of internal structure, volume and mass of glacial bodies by integrated LiDAR and ground penetrating radar surveys: The case study of Canin Eastern Glacieret (Julian Alps, Italy). Surveys in Geophysics 36(2):231-252.

https://doi.org/10.1007/s10712-014-9311-1

Connah G, Emmerson P, Stanley J. 1976. Is there a place for the proton magnetometer in Australian field archaeology? Mankind 10(3):151-155. https://doi.org/10.1111/j.1835-9310.1976.tb01145.x

Cresswell HP, Hamilton GJ. 2002. Bulk density and pore space relations. In H.P. Cresswell, N.J. McKenzie and K.J. Coughlan (eds), Soil Physical Measurement and Interpretation for Land Evaluation, pp.35-58. Melbourne: CSIRO Publishing.

Dalan RA, Musser JM, Stein JK. 1992. Geophysical exploration of the shell midden. In J.K. Stein (ed.), Deciphering a Shell Midden, pp.43-59. San Diego, CA: Academic Press Inc.

Dickson ME, Bristow CS, Hicks DM, Jol H, Stapleton J, Todd D. 2009. Beach volume on an eroding sandgravel coast determined using ground penetrating radar. Journal of Coastal Research 25(5):1149-1159. https://doi.org/10.2112/08-1137.1

Dougherty AJ, Dickson ME. 2012. Sea level and storm control on the evolution of a chenier plain, Firth of Thames, New Zealand. Marine Geology 307-310:58-72. https://doi.org/10.1016/j.margeo.2012.03.003

Faulkner, P. 2013. Life on the Margins: An Archaeological Investigation of Late Holocene Economic Variability, Coastal Blue Mud Bay, Northern Australia. ANU E Press, Canberra. 
Greenwood RS. 1961. Quantitative analysis of shells from a site in Goleta, California. American Antiquity 26(3):416-420. https://doi.org/10.2307/277409

Jacob RW, Urban TM. 2016. Ground-Penetrating Radar Velocity Determination and Precision Estimates Using Common-Midpoint (CMP) Collection with Hand-Picking, Semblance Analysis and Cross-Correlation Analysis: A Case Study and Tutorial for Archaeologists: GPR velocity determination and precision estimates. Archaeometry 58(6):987-1002. https://doi.org/10.1111/arcm.12214

Kenady SL. 2017 Geophysical Explorations of Archaeological Shell Matrix Sites: Evaluating Geophysical Techniques in Determining the Boundaries, Structure and Volume of Buried Shell Deposits. Unpublished $\mathrm{PhD}$ thesis, College of Arts, Society and Education, James Cook University, Cairns.

Kenady SL, Lowe KM, Ulm S. In Press. Determining the Boundaries, Structure and Volume of Buried Shell Matrix Deposits using Ground-Penetrating Radar: A Case Study from Northern Australia. Journal of Archaeological Science: Reports.

Kristiansen J. 2013. Fra Natur Til Kart: Veien til 3D-modellering av en isfonn ved hjelp av GIS og geofysiske metoder. Master Thesis, Faculty of Social Sciences and Technology, Norges teknisknaturvitenskapelige universitet, Trondhiem.

Langley MC, Clarkson C, Ulm S. 2011. From small holes to grand narratives: The impact of taphonomy and sample size on the modernity debate in Australia and New Guinea. Journal of Human Evolution 61(2):197208. https://doi.org/10.1016/j.jhevol.2011.03.002

Larsen BP, Holdaway SJ, Fanning PC, Mackrell T, Shiner JI. 2017. Shape as an outcome of formation history: Terrestrial laser scanning of shell mounds from far north Queensland, Australia. Quaternary International 427:5-12. https://doi.org/10.1016/j.quaint.2015.06.066

Lowe K. 2010. Archaeological Site Testing along the Mississippi Gulf Coast: Cultural Resources Investigations on Hancock and Harrison Counties Mississippi. Baton Rouge, LA: Coastal Environments, Inc.

Moffat I, Wallis LA, Beale A, Kynuna D. 2008. Trialing geophysical techniques in the identification of open indigenous sites in Australia: A case study from inland northwest Queensland. Australian Archaeology 66:60-63. http://dx.doi.org/10.1080/03122417.2008.11681868

Navarro FJ, Martín-Español A, Lapazaran JJ, Grabiec M, Otero J, Vasilenko EV, Puczko D. 2014. Ice volume estimates from ground-penetrating radar surveys, Wedel Jarlsberg Land Glaciers, Svalbard. Arctic, Antarctic, and Alpine Research 46(2):394-406. http://dx.doi.org/10.1657/1938-4246-46.2.394

Neal A, Richards J, Pye K. 2002. Structure and development of shell cheniers in Essex, southeast England, investigated using high-frequency ground-penetrating radar. Marine Geology 185(3):435-469. https://doi.org/10.1016/S0025-3227(01)00239-0

Nowroozi AA, Whittecar GR, Daniel JC.1997. Estimating the yield of crushable stone in an alluvial fan deposit by electrical resistivity methods near Stuarts Draft, Virginia. Journal of Applied Geophysics 38(1):25-40. https://doi.org/10.1016/S0926-9851(97)00014-1

O’Neil DH. 1993. Excavation sample size: A cautionary tale. American Antiquity 58(3):523-529. https://doi.org/10.2307/282111

Pluckhahn TJ, Thompson VD, Laracuente N, Mitchell S, Roberts A, Sams A. 2009. Archaeological Investigations at the Famous Crystal River Site (8cI1) (2008 Field Season), Citrus County, Florida. Tampa: The University of South Florida. 
Pluckhahn TJ, Thompson VD, Rink JW. 2016. Evidence for stepped pyramids of shell in the woodland period of eastern north America. American Antiquity 81(2):345-363. https://doi.org/10.7183/00027316.81.2.345

Pluckhahn TJ, Thompson VD, Weisman BR. 2010. Toward a new view of history and process at Crystal River (8CI1). Southeastern Archaeology 29(1):164-181. http://dx.doi.org/10.1179/sea.2010.29.1.011

Poteate AS, Fitzpatrick SM. 2013. Testing the efficacy and reliability of common zooarchaeological sampling strategies: A case study from the Caribbean. Journal of Archaeological Science 40(10):3693-3705. https://doi.org/10.1016/j.jas.2013.04.014

Prinz R, Fischer A, Nicholson L, Kaser G. 2011. Seventy-six years of mean mass balance rates derived from recent and re-evaluated ice volume measurements on tropical Lewis Glacier, Mount Kenya. Geophysical Research Letters 38(20): L20502. https://doi.org/10.1029/2011GL049208

Rodrigues SI, Porsani JL, Giannini PCF, Fornari M, Atorre T, DeBlasis P, Ruiz DMG. 2015. Radarfacies and sedimentological analysis: Study of sedimentary substrate from an archaeological site (shell mound), southern Brazil. The Holocene 25(8):1257-1270. https://doi.org/10.1177/0959683615581202

Rodrigues SI, Porsani JL, Santos VRN, DeBlasis PAD, Giannini PCF. 2009. GPR and inductive electromagnetic surveys applied in three coastal sambaqui (shell mounds) archaeological sites in Santa Catarina state, South Brazil. Journal of Archaeological Science 36(10):2081-2088.

https://doi.org/10.1016/j.jas.2009.05.013

Rosendahl D, Lowe KM, Wallis LA, Ulm S. 2014. Integrating geoarchaeology and magnetic susceptibility at three shell mounds: A pilot study from Mornington Island, Gulf of Carpentaria, Australia. Journal of Archaeological Science 49:21-32. https://doi.org/10.1016/j.jas.2014.04.017

Rucker DF, Noonan GE, Greenwood WJ. 2011. Electrical resistivity in support of geological mapping along the Panama Canal. Engineering Geology 117(1-2):121-133. https://doi.org/10.1016/j.enggeo.2010.10.012

Sambuelli L, Bava S. 2012. Case study: A GPR survey on a morainic lake in northern Italy for bathymetry, water volume and sediment characterization. Journal of Applied Geophysics 81:48-56.

https://doi.org/10.1016/j.jappgeo.2011.09.016

Santos VRN, Porsani JL, Mendonça CA, Rodrigues SI, DeBlasis PD. 2009. Reduction of topography effect in inductive electromagnetic profiles: Application on coastal sambaqui (shell mound) archaeological site in Santa Catarina state, Brazil. Journal of Archaeological Science 36(10):2089-2095. https://doi.org/10.1016/j.jas.2009.05.014

Soil Science Society of America. 1997. Glossary of Soil Science Terms. Madison, Wisconsin: Soil Science Society of America.

Tetegan M, Pasquier C, Besson A, Nicoullaud B, Bouthier A, Bourennane H, Desbourdes C, King D, Cousin I. 2012. Field-scale estimation of the volume percentage of rock fragments in stony soils by electrical resistivity. Catena 92:67-74. https://doi.org/10.1016/j.catena.2011.09.005

Thompson VD. 2007. Articulating activity areas and formation processes at the Sapelo Island shell ring complex. Southeastern Archaeology 26(1):91-107.

Thompson VD, Andrus CFT. 2011. Evaluating mobility, monumentality, and feasting at the Sapelo Island shell ring complex. American Antiquity 76(2):315-343. https://doi.org/ 10.2307/40713419 
Thompson VD, Pluckhahn TJ. 2010. History, complex hunter-gatherers, and the mounds and monuments of Crystal River, Florida, USA: A geophysical perspective. The Journal of Island and Coastal Archaeology 5(1):33-51. http://dx.doi.org/10.1080/15564890903249811

Thompson VD, Reynolds MD, Haley B, Jefferies R, Johnson JK, Humphries L. 2004. The Sapelo shell ring complex: Shallow geophysics on a Georgia sea island. Southeastern Archaeology 23(2):192-201.

Treganza AE, Cook SF. 1948. The quantitative investigation of aboriginal sites: Complete excavation with physical and archaeological analysis of a single mound. American Antiquity 13(4):287-297.

https://doi.org/10.2307/275295

Twaddle RW, Sloss CR, Lowe KM, Moss P, Mackenzie LL, Ulm S. 2017. Short-term late Holocene dry season occupation and sandy-mud flat focused foraging at Murdumurdu, Bentinck Island, Gulf of Carpentaria. Queensland Archaeological Research 20:9-46. http://dx.doi.org/10.25120/qar.20.2017.3588

Ulm S. 2002. Reassessing marine fishery intensification in southeast Queensland. Queensland Archaeological Research 13:79-96. http://dx.doi.org/10.25120/qar.13.2002.70

Van Heteren S, FitzGerald DM, Barber DC, Kelley JT, Belknap DF. 1996. Volumetric analysis of a New England barrier system using ground-penetrating-radar and coring techniques. The Journal of Geology 104(4):471-483. https://doi.org/10.1086/629840

Wang P, Li Z, Wang W, Li H, Wang F. 2014. Glacier volume calculation from ice-thickness data for mountain glaciers - A case study of glacier No. 4 of Sigong River over Mt. Bogda, eastern Tianshan, Central Asia. Journal of Earth Science 25(2):371-378. https://doi.org/10.1007/s12583-014-0427-5

Waselkov GA. 1987. Shellfish gathering and shell midden archaeology. Advances in Archaeological Method and Theory 10:93-210.

Weill P, Tessier B, Mouazé D, Bonnot-Courtois C, Norgeot C. 2012. Shelly cheniers on a modern macrotidal flat (Mont-Saint-Michel bay, France) - Internal architecture revealed by ground-penetrating radar.

Sedimentary Geology 279:173-186. https://doi.org/10.1016/j.sedgeo.2010.12.002

Yde JC, Gillespie MK, Loland R, Ruud H, Mernild SH, De Villiers S, Knudsen NT, Malmros JK. 2014. Volume measurements of Mittivakkat Gletscher, southeast Greenland. Journal of Glaciology 60(224):11991207. https://doi.org/10.3189/2014JoG14J047 